\title{
RAS proto-oncogene in medullary thyroid carcinoma
}

\author{
Margarida M Moura', Branca M Cavaco ${ }^{1}$ and Valeriano Leite ${ }^{1,2,3}$ \\ ${ }^{1}$ Unidade de Investigação em Patobiologia Molecular (UIPM), Instituto Português de Oncologia de Lisboa Francisco \\ Gentil E.P.E., Rua Prof. Lima Basto, 1099-023 Lisboa, Portugal \\ ${ }^{2}$ Serviço de Endocrinologia, Instituto Português de Oncologia de Lisboa Francisco Gentil E.P.E., \\ Rua Prof. Lima Basto, 1099-023 Lisboa, Portugal \\ ${ }^{3}$ Clínica Universitária de Endocrinologia, Faculdade de Ciências Médicas, Universidade Nova de Lisboa, \\ Campo Mártires da Pátria 130, 1150-228 Lisboa, Portugal
}

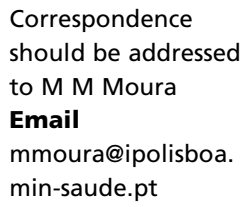

\begin{abstract}
Medullary thyroid carcinoma (MTC) is a rare malignancy originating from the calcitoninsecreting parafollicular thyroid C cells. Approximately $75 \%$ of cases are sporadic. Rearranged during transfection (RET) proto-oncogene plays a crucial role in MTC development. Besides $R E T$, other oncogenes commonly involved in the pathogenesis of human cancers have also been investigated in MTC. The family of human RAS genes includes the highly homologous HRAS, KRAS, and NRAS genes that encode three distinct proteins. Activating mutations in specific hotspots of the RAS genes are found in about $30 \%$ of all human cancers. In thyroid neoplasias, RAS gene point mutations, mainly in NRAS, are detected in benign and malignant tumors arising from the follicular epithelium. However, recent reports have also described RAS mutations in MTC, namely in HRAS and KRAS. Overall, the prevalence of RAS mutations in sporadic MTC varies between $0-43.3 \%$, occurring usually in tumors with WT $R E T$ and rarely in those harboring a RET mutation, suggesting that activation of these proto-oncogenes represents alternative genetic events in sporadic MTC tumorigenesis. Thus, the assessment of RAS mutation status can be useful to define therapeutic strategies in RET WT MTC. MTC patients with RAS mutations have an intermediate risk for aggressive cancer, between those with RET mutations in exons 15 and 16, which are associated with the worst prognosis, and cases with other RET mutations, which have the most indolent course of the disease. Recent results from exome sequencing indicate that, besides mutations in $R E T$, HRAS, and KRAS, no other recurrent driver mutations are present in MTC.
\end{abstract}

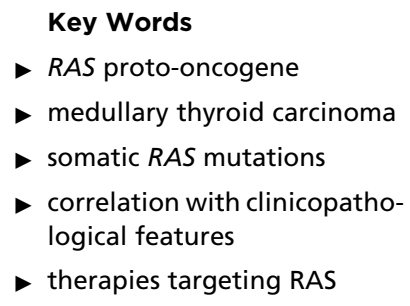

Endocrine-Related Cancer (2015) 22, R235-R252

\section{RAS in human cancer Introduction}

RAS research begins in 1964 with an observation by Jennifer Harvey (1964) that a murine leukemia virus, obtained from a leukemic rat, induced sarcomas in newborn rodents. Three additional retroviruses were subsequently identified in 1967 (Kirsten-MSV) (Kirsten \& Mayer 1967), 1974 (BALB-MSV) (Peters et al. 1974), and
1978 (Rasheed strain of rat sarcoma virus) (Rasheed et al. 1978), and later were found to carry $R A S$ oncogenes.

For the Harvey and Kirsten strains, ras was the acronym chosen for rat sarcoma, because of their ability to cause these tumors. Their discoverers' names became the basis for distinguishing them: Harvey and Kirsten viral

Published by Bioscientifica Ltd. 
ras genes, or H-ras and K-ras. The nucleotide sequences of the H-ras and K-ras oncogenes were not published until 1982 (Dhar et al. 1982, Tsuchida et al. 1982).

The molecular cloning of a human transforming gene from the EJ/T24 bladder carcinoma cell line (Goldfarb et al. 1982, Pulciani et al. 1982, Shih \& Weinberg 1982) revealed that the molecular basis of HRAS gene activation was a single missense mutation in codon 12 , which was also found in the viral H-ras and K-ras genes (Reddy et al. 1982, Tabin et al. 1982, Taparowsky et al. 1982). The mechanism of KRAS activation from lung and colon tumor cells proved also to be the mutation of codon 12 (Capon et al. 1983). In 1983, a new human transforming gene, not previously found in retroviruses, was identified (Hall et al. 1983, Shimizu et al. 1983) as a third member of the RAS gene family. This gene was discovered in neuroblastomaderived DNA and was named NRAS.

In addition to mutations at codon 12, RAS mutations were later identified at codons 13 and 61. Mutations affecting other regions of the RAS genes have also been found, but at very low frequencies. Therefore, these three codons harbor about $92-98 \%$ of all RAS mutations in human cancer and thus represent the hotspots of RAS activation.

The recent identification of germline RAS mutations in a class of genetic syndromes affecting normal development (RASopathies) implicates the aberrant RAS signaling in other human disorders (Tidyman \& Rauen 2009), and expands the use of anti-RAS drugs, originally designed as anti-cancer therapies, as obvious potential therapies for these distinct developmental disorders.

\section{Mechanism of oncogenic activation}

In humans, the three ubiquitously expressed $R A S$ genes encode four distinct but highly homologous $\sim 21 \mathrm{kDa}$ proteins (known as p21): HRAS, NRAS, KRAS4A, and KRAS4B (the last two are alternative splice variants of the KRAS gene). These proteins are GTPases that function as molecular switches in regulating pathways that are responsible for diverse cellular processes such as proliferation, differentiation, migration, and apoptosis (Boguski \& McCormick 1993). RAS proteins serve as transducers of signals that connect cell surface receptors to intracellular effector pathways, by switching between 'on' and 'off' conformations, which are conferred by the binding of GTP and GDP respectively. The transition between these two states, under physiological conditions, is regulated both by guanine nucleotide exchange factors, which induce RAS protein activation by promoting GDP for GTP exchange, and by GPTase-activating proteins, which enhances RAS-mediated GTP hydrolysis. The major effect of the most common somatic mutations present in the oncogenic variants of RAS alleles is the maintenance of RAS in the GTP-bound state, with the consequent constant activation of a variety of RAS-dependent downstream effector pathways (Pylayeva-Gupta et al. 2011).

\section{Incidence of somatic RAS mutations in human cancer}

Oncogenic activation of RAS proteins due to missense mutations is frequently detected in several types of cancer. Different databases have collected all the existing information about specific mutations of RAS genes in different forms of human tumors. For instance, the Wellcome Trust Sanger Institute has launched a catalogue of somatic mutations in cancer (COSMIC) at http://sanger.ac.uk/ cosmic, the most comprehensive database on human tumor mutations currently available (Forbes et al. 2011).

Based on the data obtained from the COSMIC dataset, $30.1 \%$ of all human tumors screened carry some mutation in any of the common RAS genes. KRAS is by far the most frequently mutated isoform, with oncogenic KRAS mutations being detected in $21.2 \%$ of all tumors analyzed (29 557 mutated samples of 139474 samples tested). The frequency of somatic mutations concerning the other family members is much lower, namely 5.7 and $3.2 \%$ of samples screened for NRAS (3587 mutated samples of 62609 samples tested) and HRAS (1127 mutated samples of 35366 samples tested) respectively. However, these values are biased, because colorectal cancer, where KRAS mutations predominate, represents most of the cases (Prior et al. 2012). So when all cancer types are given equal weightings, the average pan-RAS mutation incidence is only $14.4 \%$ (34 271 mutated samples of 237449 samples tested).

KRAS mutations are predominant in pancreatic tumors $(57.3 \%)$ and significantly high percentages are also reported in tumors of the large intestine (34.7\%), peritoneum $(28.3 \%)$, biliary tract $(25.2 \%)$, small intestine (19.5\%), lung (16.9\%), endometrium $(15.2 \%)$, ovary (12.4\%), and cervix (7.3\%). HRAS mutations are most frequently detected in tumors of the skin (10.0\%), salivary gland $(9.4 \%)$, urinary tract $(9.3 \%)$, cervix $(8.4 \%)$, upper aerodigestive tract $(7.9 \%)$, and penis $(7.1 \%)$. By contrast, NRAS mutations have higher incidence in tumors of the skin (15.4\%), hematopoietic malignancies $(9.6 \%)$, tumors of the meninges $(7.2 \%)$, and in thyroid carcinomas (6.2\%).

Oncogenic mutations are concentrated within two hotspots (codons 12/13 and 61, which participate in the

Published by Bioscientifica Ltd. 
GTP binding domain of the protein) for all RAS family members. However, the incidence of mutation at both sites varies among the three different main RAS isoforms. For KRAS, the majority of activating mutations are located at codons 12 and 13, which account for $96.3 \%$ of the mutations detected ( 81.9 and $14.4 \%$ respectively), whereas mutations affecting codon 61 account for only $1.6 \%$. Although the biological and prognostic significance of other mutations described along this oncogene locus are largely unknown, mutations in exon 4 of KRAS were found to occur commonly and to predict a more favorable clinical outcome in patients with colorectal cancer (Janakiraman et al. 2010). Another work identified a novel KRAS co-mutation that altered codons 19 and 20, resulting in transitions at both codons (p.Leu19Phe/p. Thr20Ala) in the same allele, in a human colorectal cancer, and demonstrated that co-mutation of these codons is functionally significant (Naguib et al. 2011). Activating mutations of NRAS show a different distribution pattern, with $60.9 \%$ of the mutations occurring at codon 61 and a lower percentage of mutations found at codons 12 (23.4\%) and $13(11.4 \%)$. Finally, HRAS mutations follow another specific pattern, with the highest rates of mutation observed in codon 12 (36.7\%), followed by codon 61 (34.9\%) and codon 13 (20.6\%).

Other alternative mechanisms, such as gene amplification, may also lead to RAS activation and contribute to the development of human neoplasia (Pulciani et al. 1985).

\section{Specific patterns of RAS mutations in thyroid tumors derived from the follicular epithelium}

In 1988, activating mutations of all three RAS oncogenes were first described in thyroid tumors (Lemoine et al. 1988, Suárez et al. 1988). Early reports demonstrated that the overall rate of RAS mutation in papillary carcinomas was significantly lower than in follicular carcinomas (Wright et al. 1989). Moreover, the frequency of RAS oncogene activation was similar in benign and malignant thyroid neoplasms, supporting the argument that mutation of $R A S$ oncogenes is an early event in thyroid tumorigenesis (Namba et al. 1990). Subsequent studies on RAS oncogenes in thyroid tumors showed that most of the published series reported distinct results concerning the incidence of mutations, isoform pattern and correlation of mutations with histology (Vasko et al. 2003).

$R A S$ mutations are found in a distinct percentage of thyroid cancers (Table 1). As reported in the current COSMIC somatic mutation database, NRAS mutations are
Table 1 Distribution and frequency of somatic RAS mutations in human malignant thyroid tumors

\begin{tabular}{|c|c|c|c|}
\hline $\begin{array}{l}\text { Thyroid } \\
\text { tumor type }\end{array}$ & HRAS & KRAS & NRAS \\
\hline $\begin{array}{l}\text { Anaplastic } \\
\text { carcinoma }\end{array}$ & $4.6 \%(22 / 476)$ & $8.1 \%(38 / 471)$ & $15.4 \%(72 / 467)$ \\
\hline $\begin{array}{l}\text { Follicular } \\
\quad \text { carcinoma }\end{array}$ & $6.3 \%(31 / 495)$ & $3.9 \%(19 / 490)$ & $15.7 \%(79 / 502)$ \\
\hline $\begin{array}{l}\text { Medullary } \\
\text { carcinoma }\end{array}$ & $9.3 \%(52 / 560)$ & $3.0 \%(17 / 561)$ & $0.6 \%(3 / 537)$ \\
\hline $\begin{array}{l}\text { Papillary } \\
\text { carcinoma }\end{array}$ & $1.8 \%(44 / 2416)$ & $1.2 \%(36 / 2948)$ & $4.2 \%(136 / 3210)$ \\
\hline
\end{tabular}

Data obtained from the catalogue of somatic mutations in cancer (COSMIC) at http://sanger.ac.uk/cosmic (accessed May 2014). Values are presented as the total percentage of samples mutated (total mutated samples/total samples tested) for that particular tumor type.

the most frequent $R A S$ mutations in thyroid tumors (6.2\%), followed by mutations in HRAS (3.9\%) and KRAS (2.0\%). RAS mutations have been detected in $40-50 \%$ of follicular carcinomas and $20-40 \%$ of follicular adenomas, and in oncocytic tumors but at lower frequency (Albarel et al. 2012). Several studies report that $R A S$ mutations are a marker for aggressive thyroid cancer behavior and poor prognosis (Garcia-Rostan et al. 2003). In a recent report, $R A S$ mutational analysis was performed in a series of 26 anaplastic thyroid carcinomas (ATCs) and 22 poorly differentiated thyroid carcinomas (PDTCs). In this study, NRAS was the most frequently mutated RAS oncogene isoform (26.9\% in ATC and $18.2 \%$ in PDTC) and HRAS mutations were only present in ATC (3.8\%), and no mutations were observed in KRAS either in ATC or PDTC (Pita et al. 2014).

RAS mutations have also been detected in medullary thyroid carcinomas (MTCs), and this subject will be further discussed in section ' $R A S$ mutations in MTC'.

\section{Medullary thyroid carcinoma}

MTC is a neuroendocrine tumor originating from the calcitonin-producing neural crest-derived parafollicular $\mathrm{C}$ cells of the thyroid. They are named $\mathrm{C}$ cells due to their calcitonin hormone secretion and account for up to $1 \%$ of thyroid cells. These cells are mostly located in the posterior upper third of the lateral lobes of the thyroid gland, where the majority of MTC are found, and they also produce carcinoembryonic antigen (Stamatakos et al. 2011).

MTC was first described by Jaquet (1906) as 'malignant goiter with amyloid'. Hazard et al. (1959) characterized the medullary carcinoma and recommended its recognition as a distinct clinicopathological entity. Williams (1966)

Published by Bioscientifica Ltd. 
suggested that this tumor is derived from the parafollicular cells. MTC is a relatively rare carcinoma, representing $5-10 \%$ of all thyroid cancers, and accounts for up to $14 \%$ of all thyroid cancer-related deaths (Roman et al. 2006), with $\sim 1000$ new diagnoses in the USA each year (Pacini et al. 2010).

MTC typically grows slowly and metastasizes to cervical and mediastinal nodal chains in up to $50 \%$ of cases. It also metastasizes to distant organs such as the lungs, liver, and bones in 20\% of cases (Maliszewska et al. 2013). MTC is classically managed with surgery and, unlike DTC, MTC is not iodine avid and treatment with radioactive iodine is not indicated. Moreover, the prognosis of MTC is intermediate between well-DTC and ATC, being less favorable than that of papillary thyroid carcinoma (PTC) and follicular thyroid carcinoma.

The 10-year overall survival rate of MTC is about $75 \%$ (Hundahl et al. 1998), but it decreases to $40 \%$ or less in patients with locally advanced or metastatic disease (Wells et al. 2012). Important prognostic factors that predict adverse outcome include advanced age at diagnosis, extent of primary tumor, nodal disease, and distant metastases (American Thyroid Association Guidelines Task Force et al. 2009). The occurrence of locoregional and distant metastases occurs preferentially within the first 5 years (Peixoto Callejo et al. 2006). There has been limited success in the use of systemic chemotherapy or radiotherapy to treat patients with metastatic MTC (Martins et al. 2006). Surgical removal of all malignant tissue performed at an early stage, when the disease is confined to the thyroid gland, is the only potentially curative treatment, and management guidelines for treatment of MTC were published by the American Thyroid Association (American Thyroid Association Guidelines Task Force et al. 2009).

MTC occurs in either sporadic (75\%) or hereditary (25\%) form, and is transmitted in an autosomal dominant pattern with a nearly $100 \%$ level of penetrance (Ponder et al. 1988), either as familial MTC without other endocrinopathies or as part of the multiple endocrine neoplasia (MEN) syndromes types $2 \mathrm{~A}$ and $2 \mathrm{~B}$. The most aggressive variant of MTC is MEN2B. Since the seminal description by Wolfe et al. (1973), C-cell hyperplasia $(\mathrm{CCH})$ has become recognized as a precursor to malignant transformation. Individuals affected with inherited MTC develop initially primary $\mathrm{CCH}$ that progresses to early invasive medullary microcarcinoma, and eventually evolves into grossly invasive macroscopic MTC. Familial forms often appear as multifocal and bilateral tumors developing at a young age (Schulten et al. 2011), whereas in sporadic cases, the tumor is usually unifocal and discovered in the fifth or sixth decade of life (Heshmati et al. 1997). At diagnosis, patients with sporadic MTC most commonly present with an isolated thyroid nodule or a palpable cervical lymph node.

The rearranged during transfection (RET) protooncogene is the susceptibility gene for hereditary MTC. The RET gene was first identified in 1985 (Takahashi et al. 1985), and in 1993 and 1994 it was demonstrated that MEN2 syndromes were caused by germline RET mutations (Donis-Keller et al. 1993, Eng et al. 1994). Thus, constitutively activating RET point mutations occurring germline are present in virtually all patients with inherited MTC (Kouvaraki et al. 2005). The RET gene, composed of 21 exons, is mapped to chromosome 10q11.2 and encodes a tyrosine kinase receptor with a cysteine-rich extracellular domain, a transmembrane domain and an intracellular portion containing two tyrosine kinase domains. The RET gene plays a crucial role in regulating cell proliferation, migration, differentiation, and survival (Eng 1999).

RET mutations involved in MTC are gain-of-function alterations that increase RET kinase activity, resulting in a constant activation of several intracellular signaling cascades that lead ultimately to tumor growth. Several germline mutations of this gene have been associated with hereditary MTC and a strong genotype-phenotype correlation has been reported, with mutations in exons 10 or 11 occurring mainly in individuals with MEN2A and the p.Met918Thr mutation in exon 16 being found in the majority of MEN2B cases (Maliszewska et al. 2013). The presence of specific RET mutations determines the age of presentation and aggressiveness of the tumor (Cote \& Gagel 2003). Point mutations in the RET gene cluster in exons $5,8,10,11,13-16$, and exons 5 and 8 have been added recently to the routine panel of studied exons in MTC (Romei et al. 2011). Identification of a RET germline mutation is the definitive method to distinguish sporadic from inherited forms. RET molecular analysis is essential in MTC management, since early diagnosis improves prognosis and allows genetic screening and recommendations for prophylactic thyroidectomy in familial cases (American Thyroid Association Guidelines Task Force et al. 2009).

Although much is known about hereditary MTC, the oncogenic mechanisms underlying sporadic MTC are not so well characterized. Molecular studies have demonstrated the involvement of RET proto-oncogene in $12-100 \%$ of the sporadic forms of MTC, depending on the reported series (Moura et al. 2009). p.Met918Thr RET mutation is the most common mutation in sporadic MTC

Published by Bioscientifica Ltd. 
but its detection rate varies greatly $(5-66 \%)$ in the published literature (Moura et al. 2009).

Somatic RET mutations have been correlated with a worse outcome (Ciampi et al. 2013) and associated with larger tumors, lymph node and distant metastases, more advanced stage at diagnosis and low overall survival, as well as male gender and young age at diagnosis (Dvorakova et al. 2008, Elisei et al. 2008, Mian et al. 2011). However, there are studies reporting no statistically significant association between clinical and pathological characteristics, and the presence or absence of somatic RET mutations (Tamburrino et al. 2012, Lyra et al. 2014).

In a recent study (Moura et al. 2009), somatic RET mutations were correlated with clinicopathological features of sporadic MTC and the results suggested a stratification of sporadic MTC patients into risk levels: patients with mutations in RET exons 15 and 16 were at the highest risk for aggressive MTC, followed by those having no detectable RET mutation, at intermediate risk, and patients bearing other RET mutations, who presented the lowest risk for a worse clinical outcome. Therefore, this study showed that RET mutations in exons 15 and 16 are associated with a more aggressive behavior than other RET mutations, as it has been shown in vitro, as well as in the hereditary variants of MTC.

\section{Molecular alterations beyond RET mutations in MTC}

\section{Copy number alterations}

Fluorescence in situ hybridization and real-time quantitative PCR revealed RET copy number alterations (CNA) in $27.7 \%$ MTC, represented either by RET gene amplification (exclusively in hereditary MTC) or chromosome 10 aneuploidy (more frequently observed in sporadic cases). These alterations were present in a variable percentage of cancer cells, suggesting a certain degree of tumoral heterogeneity in MTC. Moreover, a significant higher prevalence of RET CNA was observed in RET mutated MTC and correlated with a poor prognosis (Ciampi et al. 2012). Using array comparative genomic hybridization in primary tumors and metastases, it was shown that most MTC have only a few copy number changes (most commonly losses of chromosomes $1 \mathrm{p}, 4 \mathrm{q}, 19 \mathrm{p}$, and 22q) and some ( $\sim 23 \%)$ do not even present any chromosomal gains and losses, indicating that, unlike most other tumor types (Pinkel \& Albertson 2005), copy number changes in MTC are relatively rare (Flicker et al. 2012).

\section{Gene and protein expression profile}

Concerning protein expression profiling, one study assessed nuclear factor-kB (NF-kB) in a series of MTC in correlation with RET mutation status. NF-kB is a transcription factor implicated in a wide variety of cellular processes including cell growth, differentiation, and apoptosis and is known to be activated through several signaling pathways that involve growth factor receptors. NF-kB expression was more frequently altered in MTC with germline or somatic RET mutations than in cases without RET mutations, supporting the hypothesis that RET activation may be responsible for NF-kB overexpression in MTC (Gallel et al. 2008).

Sponziello et al. (2014) analyzed the expression levels of several genes involved in the epigenetic control of transcription by TaqMan low density arrays in a series of 54 MTC (13 familial and 41 sporadic, 33 carrying a RET mutation, and 13 a RAS somatic mutation). In this study, only overexpression of the histone acetyltransferases $K A T 2 A$ and $K A T 2 B$ and of histone demethylase KDM5B was observed in $R A S$-mutated compared to WT tumors. By contrast, RET-mutated tumors (both germline and somatic) showed higher transcript levels of many epigenetic regulators than both WT and RAS-mutated MTC; significant differences were detected in the expression levels of HDAC3, 6, 7, 8 and 10, EP300, KAT2A and $B$, SMYD4, CARM1, EHMT1, KDM1A, 2A, 4A, 4C and 5B, $D N M T 1$ and $3 A$. In the more aggressive MTC cases (i.e., occurrence of lymph node and distant metastases, persistent disease after primary treatment and diseaserelated death), the expression profiling revealed a significant increase of the histone methyltransferases EZH2 and SMYD3 expression, but no significant correlation was found with RET or RAS mutational status; however, a comparison with type or risk level of RET mutations was not performed.

\section{MicroRNA}

Dysregulation in microRNA (miRNA) expression has recently been implicated in the pathogenesis of many types of human cancers, including MTC (Nikiforova et al. 2008). In a series of 19 MTC, a signature of three miRNA (miR-183, miR-375, and miR-9*) enabled to distinguish familial from sporadic cases (Abraham et al. 2011). Mian et al. (2012) analyzed the expression of nine miRNA (miR-21, miR-127, miR-154, miR-224, miR-323, miR-370, miR-9*, miR-183, and miR-375) in 34 sporadic MTC and correlated this expression with RET status. From the whole

Published by Bioscientifica Ltd 
set of nine miRNA, only miR-127 was significantly associated with RET status, with sporadic MTC carrying somatic RET mutations showing a lower upregulation of this miRNA than those with a WT RET. No relationships with $R A S$ somatic mutation were observed.

The oncomiR miR-21 specifically targets the tumor suppressor gene $P D C D 4$, and recent studies suggest that PDCD4 is also regulated by protein kinase B (AKT) (Fassan et al. 2012). In a large series of 64 MTC (56 sporadic and eight familial), Pennelli et al. (2015) demonstrated significant PDCD4 nuclear downregulation together with miR-21 upregulation, thus confirming their previous results obtained in a small series of MTC (Mian et al. 2012), and showed also that miR-21/PDCD4 expression correlates with clinicopathological findings and prognosis. Although these authors were unable to detect any significant correlation between the miR-21/PDCD4 pathway and somatic RET or RAS mutation status, they found that the six RAS-positive cases in their series of MTC sporadic tumors had higher nuclear PDCD4 expression levels than the RET-positive/RAS-negative or RET/RAS WT patients. $R A S$-positive cases also revealed an intense reactivity pattern for phospho-AKT on western blot analysis, indicating a preferential activation of the phosphatidylinositol 3-kinase (PI3K)/AKT/mammalian target of rapamycin (mTOR) pathway. It has been shown that phosphorylation of PDCD4 by AKT causes nuclear translocation and inhibits tumor suppressor function of PDCD4 (Palamarchuk et al. 2005), suggesting that in RAS-positive tumors PDCD4 is hypofunctional due to the interference of AKT.
In a recent study, the expression of four main genes involved in miRNA biogenesis (DROSHA, DICER, DGCR8, and XPO5) was investigated in a series of 54 MTC analyzed for RET and RAS mutations (Puppin et al. 2014). Overexpression of DICER, DGCR8, and XPO5 was observed only in RET-mutated tumors (familial or sporadic) compared to $R E T$ WT, while RAS-mutated MTC did not show significant differences with respect to non-mutated tumors. When MTC with RET and RAS mutations were compared, only $D G C R 8$ was significantly overexpressed in RET-mutated tumors.

Taken together, miRNA may be useful as prognostic markers and represent new potential targets for a RNAbased therapy in the treatment of MTC.

\section{Gene mutations}

Few non-RET molecular alterations have been reported in MTC (Fig. 1). Of note, mutations in TP53 and RB1 are highly uncommon or absent in MTC (Yana et al. 1992, Yoshimoto et al. 1992, Herfarth et al. 1997, Agrawal et al . 2013). Some studies showed the presence of somatic loss of function mutations in the cell cycle inhibitor CDKN2C $\left(\mathrm{p} 18^{\mathrm{INK} 4 \mathrm{C}}\right)$ in about $10 \%$ of human MTC, coexisting with activating RET mutations, and concluded that loss of function of this tumor suppressor gene contributes to RET-induced MTC development (van Veelen et al. 2009); however, other authors did not find CDKN2C mutations in MTC samples (Cerrato et al. 2009). Our group also looked for mutations in $C D K N 1 B\left(\mathrm{p} 18^{\mathrm{INK} 4 \mathrm{C}}\right)$ and CDKN2C (p27 ${ }^{\mathrm{KIP} 1}$ ) genes in RET WT sporadic MTC patients and,

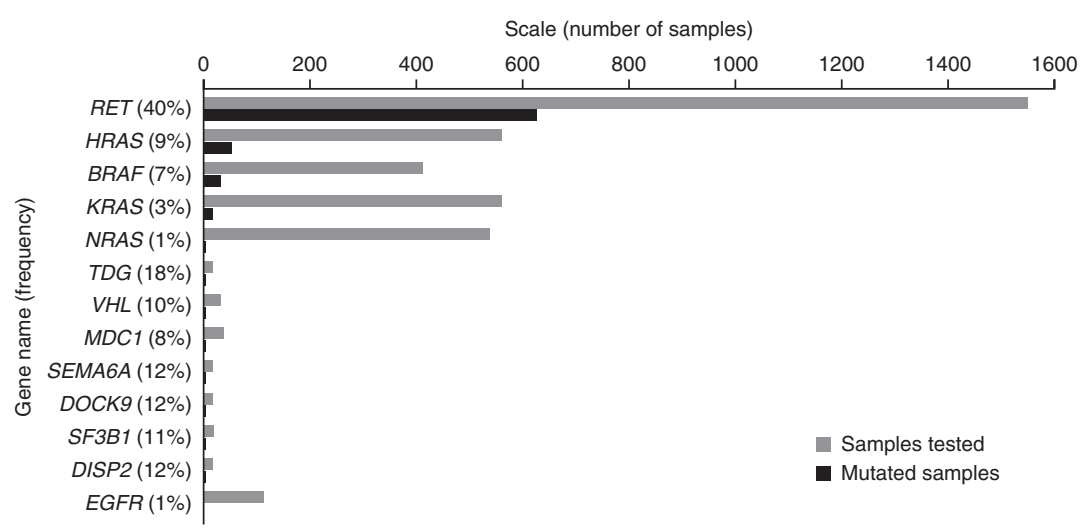

Figure 1

Summary of the most frequently mutated genes in MTC. The graph represents the genes that are mutated in at least two samples, or only in a single sample but after being tested in more than 100 MTC.
(C) 2015 Society for Endocrinology Printed in Great Britain
The data relate to the COSMIC v68 release, at http://sanger.ac.uk/cosmic (accessed May 2014).

Published by Bioscientifica Ltd. 
except for an unreported germline CDKN2C variant (p.Pro117Ser) detected in one patient carrying a somatic HRAS mutation (p.Gly13Arg), no other mutations were found; no mutations were detected in VHL gene either in our series (M M Moura, B M Cavaco and V Leite, unpublished observations), although one (Koch et al. 2006) and two (Koperek et al. 2011) somatic VHL mutations have been previously described in hereditary and sporadic MTC respectively.

Many other oncogenes usually involved in the pathogenesis of various tumor types have been investigated in MTC with little success (Cerrato et al. 2009). MTC showed no genetic changes in c-myc, N-myc, and c-erbB proto-oncogenes (Yang et al. 1990), such as found commonly in human neoplasms, and absence of missense mutations of Gsa and Gi2a genes has also been observed in MTC (Horie et al. 1995). EGFR and JAK2 mutations, genetic alterations that constitute potential therapeutic targets for drug-designed inhibitors in lung adenocarcinomas and myeloproliferative disorders, respectively, are infrequent or absent in MTC (Ameur et al. 2009). Similarly, mutations in $A K T 1$ and CTNNB1 genes, which are key regulators of the PI3K/AKT/mTOR and canonical Wnt/ $\beta$-catenin pathways, respectively, are virtually unknown in MTC (Schulten et al. 2011). Our group found no evidence of mutations in $A K T 1, A K T 2$, and $A K T 3$ within hotspots in sporadic MTC (M M Moura, B M Cavaco and V Leite, unpublished observations).

Point mutations in genes frequently implicated in thyroid tumorigenesis and linked to the RET pathway, such as BRAF and PIK3CA, have also been investigated in MTC in limited case series (Xing 2005, Ameur et al. 2009, Schlumberger et al. 2009). PIK3CA gene has been screened in 13 cases in a single study and neither mutations nor amplification were found (Wu et al. 2005). Our group confirmed that mutations in PIK3CA, within the classical hotspots, are absent in RET WT sporadic MTC patients (M M Moura, B M Cavaco and V Leite, unpublished observations). No BRAF gene mutations have been reported in three small series of 13 (Nikiforova et al. 2003), 14 (Xing et al. 2004), and 25 (Perren et al. 2004) MTC respectively. However, in a Greek cohort of 44 sporadic MTC, BRAF mutations were detected in $68.2 \%$ of the samples (Goutas et al. 2008), a finding that was not confirmed in the most recent studies (Schlumberger et al. 2009, Moura et al. 2011, Rapa et al. 2011, Schulten et al. 2011, Boichard et al. 2012, Agrawal et al. 2013, Nikiforova et al. 2013).

Recently, it was shown that mutations in the promoter region of TERT are relatively frequent in specific types of human cancers, including PTC and ATC (Vinagre et al. 2013); however, no mutations were detected in MTC (Killela et al. 2013, Vinagre et al. 2013), nor in normal thyroid and benign lesions (such as goiters, adenomas, or thyroiditis).

\section{RAS mutations in MTC}

The presence of RAS mutations in sporadic MTC is not entirely unexpected, since Johnston et al. (1998) demonstrated the development of MTC in rascal transgenic mice expressing v-Ha-ras under the control of the calcitonin/ calcitonin gene-related peptide promoter. Also, the expression of transfected v-Ha-ras in MTC cell lines was previously shown to induce neuroendocrine differentiation in vitro (Nakagawa et al. 1987).

We performed sequencing analysis of the RAS genes in 66 sporadic MTC, 40 with RET mutation and 26 with RET WT, and somatic HRAS and KRAS mutations were detected in $15 / 26(57.7 \%)$ and $3 / 26(11.5 \%)$ of RET WT cases respectively (Moura et al. 2011; an additional sporadic MTC case was included in this series, M M Moura, B M Cavaco and V Leite, unpublished observations). Only $1 / 40$ (2.5\%) RET-positive cases had a somatic RAS mutation, namely in HRAS (p.Gly13Val). Overall, RAS mutations were present in $69.2 \%(18 / 26)$ of the RET WT cases and in only $2.5 \%$ of the RET-positive sporadic MTC $(P<0.0001)$, suggesting that activation of the protooncogenes RAS and RET represents alternative genetic events in sporadic MTC tumorigenesis. These results were confirmed by other groups (Schlumberger et al. 2009, Schulten et al. 2011, Boichard et al. 2012, Mian et al. 2012, Tamburrino et al. 2012, Agrawal et al. 2013, Ciampi et al. 2013, Nikiforova et al. 2013, Lyra et al. 2014, Puppin et al . 2014, Simbolo et al. 2014, Sponziello et al. 2014, Pennelli et al. 2015). We found no other mutations in the entire coding region of the genes HRAS, KRAS and RET in the RET and RAS WT sporadic MTC (M M Moura, B M Cavaco and $\mathrm{V}$ Leite, unpublished observations).

A comprehensive review of the studies that were published in the literature concerning the prevalence of $R A S$ point mutations in sporadic MTC is shown in Table 2. The prevalence of $R A S$ mutations in such cases varies between $0-41.2$ and $0-40.9 \%$ for HRAS and KRAS, respectively, and between $0-1.8 \%$ for NRAS, depending on the reported series.

The most frequent HRAS mutation is p.Gln61Arg $(n=35)$, followed by p.Gln61Lys $(n=20)$ and p.Gly13Arg $(n=12)$, whereas the prevalent KRAS mutation is p.Gly12Arg $(n=13)$. Since not all series analyzed all $R A S$ isoforms, we present in Table 3 the overall prevalence of

Published by Bioscientifica Ltd. 
Table 2 Prevalence of RAS point mutations in sporadic MTC

\begin{tabular}{|c|c|c|c|c|c|c|}
\hline \multirow[b]{2}{*}{ References } & \multirow{2}{*}{$\begin{array}{l}\text { No. of } \\
\text { cases }\end{array}$} & \multirow[b]{2}{*}{ Method used } & \multicolumn{4}{|c|}{ Gene } \\
\hline & & & & HRAS & KRAS & NRAS \\
\hline \multirow[t]{2}{*}{ Okazaki et al. (1989) } & 10 & Slot blot analysis & $\begin{array}{l}\text { Loci studied } \\
\text { Mutated samples }\end{array}$ & $\begin{array}{l}\text { Codons } 12 \text { and } 61 \\
1 / 10(10.0 \%)\end{array}$ & $\begin{array}{l}\text { Codons } 12,13 \text {, and } 61 \\
0 / 10(0.0 \%)\end{array}$ & $\begin{array}{l}\text { Codons } 12 \text { and } 61 \\
0 / 10(0.0 \%)\end{array}$ \\
\hline & & & Mutation (no. of patients) & p.GIn61Arg (1) & & \\
\hline \multirow[t]{3}{*}{ Bockhorn et al. (2000) } & 15 & Direct sequencing & Loci studied & Codons 12,13 , and 61 & Codons 12,13 , and 61 & NS \\
\hline & & & Mutated samples & $0 / 15(0.0 \%)$ & $0 / 15(0.0 \%)$ & NS \\
\hline & & & Mutation (no. of patients) & - & - & NS \\
\hline \multirow[t]{3}{*}{ Goutas et al. (2008) } & 44 & Restriction fragment & Loci studied & NS & Codon 12 & NS \\
\hline & & length poly- & Mutated samples & NS & $18 / 44(40.9 \%)$ & NS \\
\hline & & morphism analysis & Mutation (no. of patients) & NS & NA & NS \\
\hline \multirow[t]{2}{*}{ Schlumberger et al. (2009) } & 38 & Direct sequencing & $\begin{array}{l}\text { Loci studied } \\
\text { Mutated samples }\end{array}$ & $\begin{array}{l}\text { Exons } 2 \text { and } 3 \\
2 / 37^{\mathrm{a}}(5.4 \%)\end{array}$ & $\begin{array}{l}\text { Exons } 2 \text { and } 3 \\
1 / 38(2.6 \%)\end{array}$ & $\begin{array}{l}\text { Exons } 2 \text { and } 3 \\
0 / 38(0.0 \%)\end{array}$ \\
\hline & & & Mutation (no. of patients) & $\begin{array}{l}\text { p.GIn61Arg (1) } \\
\text { p.GIn61Lys (1) }\end{array}$ & p.Gly12Arg (1) & - \\
\hline \multirow[t]{6}{*}{ Moura et al. (2011) } & 65 & Direct sequencing & Loci studied & Exons 2 and 3 & Exons 2 and 3 & Exons 2 and 3 \\
\hline & & & Mutated samples & $15 / 65(23.1 \%)$ & $3 / 65(4.6 \%)$ & $0 / 65(0.0 \%)$ \\
\hline & & & Mutation (no. of patients) & p.Gly13Arg (5) & p.Gln61Arg (1) & - \\
\hline & & & & p.GIn61Arg (5) & p.Gln61Leu (1) & \\
\hline & & & & p.GIn61Lys (3) & p.Gln61Lys (1) & \\
\hline & & & & $\begin{array}{l}\text { p.Ala11_Gly12dup (1) } \\
\text { p.Gly13Val (1) }\end{array}$ & & \\
\hline \multirow[t]{3}{*}{ Rapa et al. (2011) } & 38 & Pyrosequencing & Loci studied & Codon 61 & Codons 12 and 13 & Codon 61 \\
\hline & & & Mutated samples & $0 / 38(0.0 \%)$ & $0 / 38(0.0 \%)$ & $0 / 38(0.0 \%)$ \\
\hline & & & Mutation (no. of patients) & - & - & - \\
\hline \multirow[t]{2}{*}{ Schulten et al. (2011) } & 9 & Direct sequencing & $\begin{array}{l}\text { Loci studied } \\
\text { Mutated samples }\end{array}$ & $\begin{array}{l}\text { Exons } 2 \text { and } 3 \\
1 / 9(11.1 \%)\end{array}$ & $\begin{array}{l}\text { Exons } 2 \text { and } 3 \\
0 / 9(0.0 \%)\end{array}$ & $\begin{array}{l}\text { Exons } 2 \text { and } 3 \\
0 / 9(0.0 \%)\end{array}$ \\
\hline & & & Mutation (no. of patients) & p.Gly13Arg (1) & - & - \\
\hline \multirow[t]{3}{*}{ Tamburrino et al. (2012) } & 17 & Exome sequencing & $\begin{array}{l}\text { Loci studied } \\
\text { Mutated samples }\end{array}$ & $\begin{array}{l}\text { Coding region } \\
4 / 17(23.5 \%)\end{array}$ & $\begin{array}{l}\text { Coding region } \\
2 / 17(11.8 \%)\end{array}$ & $\begin{array}{l}\text { Coding region } \\
0 / 17(0.0 \%)\end{array}$ \\
\hline & & & Mutation (no. of patients) & p.Gln61Arg (2) & p.Gln61Leu (1) & - \\
\hline & & & & $\begin{array}{l}\text { p.Gly13Arg (1) } \\
\text { p.Gln61Lys (1) }\end{array}$ & p.Gln61Lys (1) & \\
\hline \multirow[t]{6}{*}{ Boichard et al. (2012) } & 30 & Direct sequencing & Loci studied & Exons 2,3 , and 4 & Exons 2,3 , and 4 & Exons 2,3 , and 4 \\
\hline & & & Mutated samples & $8 / 30(26.7 \%)$ & $5 / 30(16.7 \%)$ & $0 / 30(0.0 \%)$ \\
\hline & & & Mutation (no. of patients) & p.Gln61Arg (4) & p.Ala146Val (2) & - \\
\hline & & & & p.GIn61Lys (2) & p.Gly12Arg (1) & \\
\hline & & & & p.Gly13Arg (1) & p.Gly12 Val (1) & \\
\hline & & & & p.Lys117Asn (1) & p.Glu63Lys (1) & \\
\hline \multirow[t]{8}{*}{ Ciampi et al. (2013) } & $175^{\mathrm{b}}$ & Direct sequencing & Loci studied & Exons 2 and 3 & Exons 2 and 3 & Exons 2 and 3 \\
\hline & & & Mutated samples & $13 / 175(7.4 \%)$ & $4 / 175(2.3 \%)$ & $2^{c} / 175(1.1 \%)$ \\
\hline & & & Mutation (no. of patients) & p.Gln61Arg (5) & p.Gly12Arg (3) & p.Gln61Arg (1) \\
\hline & & & & p.Gln61Lys (3) & p.Gln61His (1) & p.Gln61Leu (1) \\
\hline & & & & p.GIn61Leu (2) & & \\
\hline & & & & p.Gly12Arg (1) & & \\
\hline & & & & p.Gly13Arg (1) & & \\
\hline & & & & p.Met72lle (1) & & \\
\hline
\end{tabular}




\begin{tabular}{|c|c|c|c|c|c|c|}
\hline \multirow[b]{2}{*}{ References } & \multirow{2}{*}{$\begin{array}{l}\text { No. of } \\
\text { cases }\end{array}$} & \multirow[b]{2}{*}{ Method used } & \multicolumn{4}{|c|}{ Gene } \\
\hline & & & & HRAS & KRAS & NRAS \\
\hline Agrawal et al. (2013) & $17^{d}$ & Exome sequencing & $\begin{array}{l}\text { Loci studied } \\
\text { Mutated samples } \\
\text { Mutation (no. of patients) }\end{array}$ & $\begin{array}{l}\text { Coding region } \\
0 / 17(0.0 \%) \\
-\end{array}$ & $\begin{array}{l}\text { Coding region } \\
0 / 17(0.0 \%) \\
-\end{array}$ & $\begin{array}{l}\text { Coding region } \\
0 / 17(0.0 \%) \\
-\end{array}$ \\
\hline & $17^{e}$ & Direct sequencing & $\begin{array}{l}\text { Loci studied } \\
\text { Mutated samples } \\
\text { Mutation (no. of patients) }\end{array}$ & $\begin{array}{l}\text { Exons } 2,3,4 \text {, and } 5 \\
7 / 17(41.2 \%) \\
\text { p.GIn61Arg (5) } \\
\text { p.Gln61Lys (1) } \\
\text { p.Lys117Asn (1) }\end{array}$ & $\begin{array}{l}\text { Exons } 2,3,4 \text {, and } 5 \\
2 / 17(11.8 \%) \\
\text { p.Gly12Arg (1) } \\
\text { p.Gly12Val (1) }\end{array}$ & $\begin{array}{l}\text { NS } \\
\text { NS } \\
\text { NS }\end{array}$ \\
\hline Nikiforova et al. (2013) & 15 & $\begin{array}{l}\text { Next-generation } \\
\text { sequencing }\end{array}$ & $\begin{array}{l}\text { Loci studied } \\
\text { Mutated samples } \\
\text { Mutation (no. of patients) }\end{array}$ & $\begin{array}{l}\text { Exons } 2 \text { and } 3 \\
3 / 15(20.0 \%) \\
\text { p.GIn61 Lys (2) } \\
\text { p.Gly13Arg (1) }\end{array}$ & $\begin{array}{l}\text { Exons } 2 \text { and } 3 \\
1 / 15(6.7 \%) \\
\text { p.Gly12Arg (1) }\end{array}$ & $\begin{array}{l}\text { Exons } 2 \text { and } 3 \\
0 / 15(0.0 \%) \\
-\end{array}$ \\
\hline Puppin et al. (2014) & $41^{f}$ & Direct sequencing & $\begin{array}{l}\text { Loci studied } \\
\text { Mutated samples } \\
\text { Mutation (no. of patients) }\end{array}$ & $\begin{array}{l}\text { Exons 2, 3, and } 4 \\
9 / 41(22.0 \%) \\
\text { p.GIn61Lys (5) } \\
\text { p.Gly13Arg (2) } \\
\text { p.GIn61Arg (2) }\end{array}$ & $\begin{array}{l}\text { Exons } 2,3 \text {, and } 4 \\
4 / 41(9.8 \%) \\
\text { p.Gly12Arg (1) } \\
\text { p.Gly12Val (1) } \\
\text { p.Gln61Arg (1) } \\
\text { p.Ala146Val (1) }\end{array}$ & $\begin{array}{l}\text { Exons } 2,3 \text {, and } 4 \\
0 / 41(0.0 \%) \\
-\end{array}$ \\
\hline Simbolo et al. (2014) & 20 & $\begin{array}{l}\text { Next-generation } \\
\text { sequencing }\end{array}$ & $\begin{array}{l}\text { Loci studied } \\
\text { Mutated samples } \\
\text { Mutation (no. of patients) }\end{array}$ & $\begin{array}{l}\text { Exons } 2 \text { and } 3^{9} \\
3 / 20(15.0 \%) \\
\text { p.Gln61Arg (3) }\end{array}$ & $\begin{array}{l}\text { Exons } 2,3 \text {, and } 4^{9} \\
1 / 20(5.0 \%) \\
\text { p.Gly12Arg (1) }\end{array}$ & $\begin{array}{l}\text { Exons } 2,3 \text {, and } 4^{9} \\
0 / 20(0.0 \%) \\
-\end{array}$ \\
\hline Mancikova et al. (2014) & 57 & Direct sequencing & $\begin{array}{l}\text { Loci studied } \\
\text { Mutated samples } \\
\text { Mutation (no. of patients) }\end{array}$ & $\begin{array}{l}\text { Exons } 2 \text { and } 3 \\
10 / 57(17.5 \%) \\
\text { NA }\end{array}$ & $\begin{array}{l}\text { Exons } 2 \text { and } 3 \\
4 / 57(7.0 \%) \\
\text { NA }\end{array}$ & $\begin{array}{l}\text { Exons } 2 \text { and } 3 \\
0 / 57(0.0 \%) \\
-\end{array}$ \\
\hline Lyra et al. (2014) & 77 & Direct sequencing & $\begin{array}{l}\text { Loci studied } \\
\text { Mutated samples } \\
\text { Mutation (no. of patients) }\end{array}$ & $\begin{array}{l}\text { Exons } 2 \text { and } 3 \\
8 / 77(10.4 \%) \\
\text { p.Gln61Arg (6) } \\
\text { p.Gln61Lys (2) }\end{array}$ & $\begin{array}{l}\text { Exons } 2 \text { and } 3 \\
3 / 77(3.9 \%) \\
\text { p.Gly12Arg (2) } \\
\text { p.Gly12Ser (1) }\end{array}$ & $\begin{array}{l}\text { NS } \\
\text { NS } \\
\text { NS }\end{array}$ \\
\hline Pennelli et al. (2015) & 56 & Direct sequencing & $\begin{array}{l}\text { Loci studied } \\
\text { Mutated samples } \\
\text { Mutation (no. of patients) }\end{array}$ & $\begin{array}{l}\text { Exons } 2 \text { and } 3 \\
3 / 56(5.4 \%) \\
\text { p.Gly12Arg (1) } \\
\text { p.Gln61Arg (1) } \\
\text { p.Met72lle (1) }\end{array}$ & $\begin{array}{l}\text { Exons } 2 \text { and } 3 \\
2 / 56(3.6 \%) \\
\text { p.Gly12Arg (2) }\end{array}$ & $\begin{array}{l}\text { Exons } 2 \text { and } 3 \\
1 / 56(1.8 \%) \\
\text { p.GIn61Leu (1) }\end{array}$ \\
\hline
\end{tabular}

NA, not available; NS, not studied.

In one sample, HRAS mutation was not determined.

${ }^{6}$ Part of the series $(n=34)$ was previously reported in another publication (Mian et al. 2012).

'Both patients with NRAS mutations had a PTC in association with the MTC.

Discovery screen.

Validation screen.

This series of tumor samples was in part already analyzed in previous reports (Ameur et al. 2009, Boichard et al. 2012).

Hotspot regions. 
Table 3 Prevalence of RAS point mutations in studies where all three RAS isoforms were analyzed in sporadic MTC

\begin{tabular}{|c|c|c|}
\hline References & No. of cases & $\begin{array}{c}\text { Overall RAS } \\
\text { mutations }\end{array}$ \\
\hline Okazaki et al. (1989) & 10 & $1 / 10(10.0 \%)$ \\
\hline Schlumberger et al. (2009) & 38 & $3 / 38(7.9 \%)$ \\
\hline Moura et al. (2011) & 65 & $18 / 65(27.7 \%)$ \\
\hline Rapa et al. (2011) & 38 & $0 / 38(0.0 \%)$ \\
\hline Schulten et al. (2011) & 9 & $1 / 9(11.1 \%)$ \\
\hline Tamburrino et al. (2012) & 17 & $6 / 17(35.3 \%)$ \\
\hline Boichard et al. (2012) & 30 & $13 / 30(43.3 \%)$ \\
\hline Ciampi et al. (2013) & 175 & $19 / 175(10.9 \%)$ \\
\hline Agrawal et al. (2013) & $17^{\mathrm{a}}$ & $0 / 17(0.0 \%)$ \\
\hline Nikiforova et al. (2013) & 15 & $4 / 15(26.7 \%)$ \\
\hline Puppin et al. (2014) & 41 & $13 / 41(31.7 \%)$ \\
\hline Simbolo et al. (2014) & 20 & $4 / 20(20.0 \%)$ \\
\hline Mancikova et al. (2014) & 57 & $14 / 57(24.6 \%)$ \\
\hline Pennelli et al. (2015) & 56 & $6 / 56(10.7 \%)$ \\
\hline
\end{tabular}

${ }^{a}$ Discovery screen.

$R A S$ mutations in the studies where all $R A S$ isoforms were screened. As shown, the prevalence in these studies varies between 0-43.3\%.

Boichard et al. (2012) screened the somatic mutational status of RAS genes in a series of 50 MTC, including 30 sporadic cases, and three mutations were detected in exon 4 both of HRAS ( $n=1$, codon 117) and KRAS ( $n=2$, codon 146). Mian et al. (2012) reported a p.Met72Ile mutation in exon 3 of the HRAS gene in a case with sporadic MTC.

There are several reasons that may explain the different prevalences of $R A S$ point mutations that have been reported in MTC and that are summarized in Tables 2 and 3. First, in some of the studies, only the three mutational hotspots (codons 12, 13, and 61) were analyzed and/or not all RAS isoforms were screened. Secondly, the sizes of the published series differ substantially. Thirdly, different methodologies, with variable sensitivities for mutation detection, were used for the screening of RAS mutations. Fourthly, ethnic or environmental factors may also account for the reported differences in the prevalence of RAS mutations.

Agrawal et al. (2013) sequenced the exomes of 17 sporadic MTC and validated the frequency of all recurrently mutated genes and other genes of interest in an independent cohort of 40 MTC (21 hereditary and 19 sporadic). Wholeexome sequencing revealed that RET was somatically mutated in 12 sporadic MTC in the discovery screen, but no HRAS and KRAS mutations were detected. Other than $R E T$, the genes that were mutated in at least two of the 17 MTC were MDC1, SF3B1, MGAM, DOCK9, SEMA6A, TDG, and DISP2 (see Fig. 1). RET, HRAS, and KRAS genes were sequenced in additional 40 MTC (validation screen), and seven HRAS and two KRAS somatic mutations were detected. Thus, recent results from whole-exome sequencing indicate that MTC harbor relatively few mutations overall and suggest that there are no recurrent driver mutations other than RET, HRAS, and KRAS in these tumors.

Simbolo et al. (2014) examined the mutational status of 50 cancer-associated genes using a targeted nextgeneration sequencing (NGS) approach in a series of 20 sporadic MTC, previously analyzed for RET mutations by Sanger sequencing. Thirteen MTC harbored a somatic RET mutation; three of them, undetected by Sanger, were revealed by NGS, showing that targeted NGS has a higher sensitivity in the detection of mutations (these cases presented a proportion of RET mutated alleles below the $20 \%$ detection limit of Sanger analysis). One of the 13 RETmutated cases also had a p.Phe354Leu germline mutation in STK11, which has been found in Peutz-Jeghers syndrome (Forcet et al. 2005). Four of the seven RET WT MTC carried a RAS mutation (three in HRAS and one in $K R A S)$ and the three remaining cases were WT for all the 50 cancer-related genes. Thus, beside RET, HRAS, and KRAS mutations, no case exhibited somatic mutations in the other 47 genes studied.

As shown in Table 4, the prevalence of RAS mutations in different series of sporadic RET WT MTC varies between 0-81.3\% (0-77.8, 0-31.3, and 0-2.8\% for HRAS, KRAS, and $N R A S$ respectively). HRAS is the gene most frequently affected, followed by KRAS, while mutations in NRAS remain a rare event. This contrasts with tumors arising from the thyroid follicular cells, where NRAS predominates (Vasko et al. 2003, Zhu et al. 2003). All the studies where RET and RAS were investigated in MTC showed mutual exclusivity between RET and RAS point mutations (Schlumberger et al. 2009, Moura et al. 2011, Schulten et al. 2011, Boichard et al. 2012, Mian et al. 2012, Tamburrino et al. 2012, Agrawal et al. 2013, Ciampi et al. 2013, Nikiforova et al. 2013, Lyra et al. 2014, Puppin et al. 2014, Simbolo et al. 2014, Sponziello et al. 2014, Pennelli et al. 2015). However, a somatic HRAS mutation was detected in one RET-positive case in the series of Moura et al. (2011), and to the best of our knowledge there are no other studies describing RAS mutations in RET-positive MTC. The two MTC patients who harbored NRAS mutations in the series of Ciampi et al. (2013) also presented a concomitant PTC.

$R A S$ analyses performed in peripheral blood or normal thyroid tissue, from MTC cases harboring a RAS mutation in tumoral tissue, were negative indicating the somatic origin of the mutation. This result was expected, as germline HRAS mutations are associated with Costello's

Published by Bioscientifica Ltd 
Table 4 Prevalence of RAS point mutations in RET-negative sporadic MTC

\begin{tabular}{|c|c|c|}
\hline References & No. of cases & Gene \\
\hline \multirow[t]{3}{*}{ Schlumberger et al. (2009) } & 10 & HRAS \\
\hline & & KRAS \\
\hline & & NRAS \\
\hline \multirow[t]{3}{*}{ Moura et al. (2011) } & 25 & HRAS \\
\hline & & KRAS \\
\hline & & NRAS \\
\hline \multirow[t]{3}{*}{ Rapa et al. (2011) } & 18 & HRAS \\
\hline & & KRAS \\
\hline & & NRAS \\
\hline \multirow[t]{3}{*}{ Schulten et al. (2011) } & 5 & HRAS \\
\hline & & KRAS \\
\hline & & NRAS \\
\hline \multirow[t]{3}{*}{ Tamburrino et al. (2012) } & 10 & HRAS \\
\hline & & KRAS \\
\hline & & NRAS \\
\hline \multirow[t]{3}{*}{ Boichard et al. (2012) } & 16 & HRAS \\
\hline & & KRAS \\
\hline & & NRAS \\
\hline \multirow[t]{3}{*}{ Ciampi et al. (2013) } & 106 & HRAS \\
\hline & & KRAS \\
\hline & & NRAS \\
\hline \multirow[t]{6}{*}{ Agrawal et al. (2013) } & $5^{a}$ & HRAS \\
\hline & & KRAS \\
\hline & & NRAS \\
\hline & $9^{b}$ & HRAS \\
\hline & & KRAS \\
\hline & & NRAS \\
\hline \multirow[t]{3}{*}{ Nikiforova et al. (2013) } & 8 & HRAS \\
\hline & & KRAS \\
\hline & & NRAS \\
\hline \multirow[t]{3}{*}{ Puppin et al. (2014) } & 21 & HRAS \\
\hline & & KRAS \\
\hline & & NRAS \\
\hline \multirow[t]{3}{*}{ Simbolo et al. (2014) } & 7 & HRAS \\
\hline & & KRAS \\
\hline & & NRAS \\
\hline \multirow[t]{3}{*}{ Mancikova et al. (2014) } & 29 & HRAS \\
\hline & & KRAS \\
\hline & & NRAS \\
\hline \multirow[t]{3}{*}{ Lyra et al. (2014) } & 41 & HRAS \\
\hline & & $K R A S$ \\
\hline & & NRAS \\
\hline \multirow[t]{3}{*}{ Pennelli et al. (2015) } & 36 & HRAS \\
\hline & & $K R A S$ \\
\hline & & NRAS \\
\hline
\end{tabular}

\section{Mutated samples (RAS+/RET-)

Mutated samples (RAS +IRET-)

$2 / 10(20.0 \%)$
$1 / 10(10.0 \%)$
$0 / 10(0.0 \%)$

$14 / 25(56.0 \%)$

$3 / 25(12.0 \%)$

$0 / 25(0.0 \%)$

$0 / 18(0.0 \%)$

$0 / 18(0.0 \%)$

$0 / 18(0.0 \%)$

$1 / 5(20.0 \%)$

$0 / 5(0.0 \%)$

$0 / 5(0.0 \%)$

$4 / 10(40.0 \%)$

$2 / 10(20.0 \%)$

$0 / 10(0.0 \%)$

$8 / 16(50.0 \%)$

$5 / 16(31.3 \%)$

$0 / 16(0.0 \%)$

$13 / 106(12.3 \%)$

$4 / 106(3.8 \%)$

$2 / 106(1.9 \%)$

$0 / 5(0.0 \%)$

$0 / 5(0.0 \%)$

$0 / 5(0.0 \%)$

$7 / 9(77.8 \%)$

$2 / 9(22.2 \%)$

NS

$3 / 8(37.5 \%)$

$1 / 8(12.5 \%)$

$0 / 8(0.0 \%)$

$9 / 21(42.9 \%)$

$4 / 21(19.0 \%)$

$0 / 21(0.0 \%)$

$3 / 7(42.9 \%)$

$1 / 7(14.3 \%)$

$0 / 7(0.0 \%)$

$10 / 29(34.5 \%)$

$4 / 29(13.8 \%)$

$0 / 29(0.0 \%)$

$8 / 41(19.5 \%)$

$3 / 41(7.3 \%)$

NS

$3 / 36(8.3 \%)$

$2 / 36(5.6 \%)$

$1 / 36(2.8 \%)$

\begin{tabular}{c}
\hline Overall RAS mutations \\
\hline $3 / 10(30.0 \%)$ \\
$17 / 25(68.0 \%)$ \\
$0 / 18(0.0 \%)$ \\
$1 / 5(20.0 \%)$ \\
$6 / 10(60.0 \%)$ \\
$13 / 16(81.3 \%)$ \\
$19 / 106(17.9 \%)$ \\
$4 / 36(16.7 \%)$ \\
$9 / 14(64.3 \%)$ \\
\end{tabular}

NS, not studied.

aDiscovery screen.

balidation screen.

syndrome and germline KRAS mutations are responsible for Noonan's syndrome, which are developmental disorders caused by dysregulation of the RAS/RAF/MEK/ ERK pathway (Tidyman \& Rauen 2009).

It has already been demonstrated that the mTOR pathway is activated in sporadic and hereditary MTC (Rapa et al. 2011, Tamburrino et al. 2012) with a preferential expression in cases with germline RET mutations (Rapa et al. 2011). However, it remains unknown whether RAS mutations can also lead to the activation of this signaling pathway in MTC. Lyra et al. (2014) evaluated mTOR activation in a series of 87 MTC (ten familial and 77 sporadic), and RAS mutations were significantly associated with higher intensity of phosphoS6 ribosomal protein (p-S6) (a downstream effector of mTOR) expression; a significantly lower cytoplasmic expression of PTEN (a mTOR inhibitor) was observed in WT RAS cases in comparison with those with $R A S$

Published by Bioscientifica Ltd. 
mutation. These results reveal an association between the activation of the mTOR pathway and the presence of RAS mutations in MTC, and this is in accordance with recent findings of Pennelli et al. (2015), as mentioned before (see section 'Molecular alterations beyond RET mutations in MTC').

\section{Correlation of RET and RAS somatic mutations with clinicopathological features in sporadic MTC}

It order to correlate RET and RAS mutations with clinical and pathological characteristics, our series of MTC patients (Moura et al. 2011) was divided into four groups (Table 5): group 1, with mutations in RET exons 15 and 16 $(n=24,36.4 \%)$ which includes somatic p.Met918Thr and p.Ala883Phe RET mutation cases, as patients with American Thyroid Association (ATA) level D mutations (codons 883 and 918) are at the highest risk for early development and growth of MTC (Frank-Raue et al. 2010); group 2, bearing other RET mutations ( $n=15,22.7 \%)$; group 3, carrying a RAS mutation but no RET mutation ( $n=18,27.3 \%)$; and group 4 , having no detectable RET or RAS mutations ( $n=8,12.1 \%)$. One RAS-positive/ $R E T$-positive case $(n=1,1.5 \%)$ was excluded. Group 1 had higher prevalence of lymph node $(P=0.0014)$ and distant $(P=0.017)$ metastases, higher number of positive lymph nodes $(P=0.0011)$, were more frequently associated with stage IV $(P=0.005$, vs stages I-III), and presented more often multifocal tumors $(P=0.008)$, than cases with other RET mutations. Patients having no RET mutations (either RAS-positive or $R A S$-negative) were at intermediate risk and there was no statistically significant difference between $R A S$-positive and $R A S$-negative patients. In conclusion, these findings indicate that, among the sporadic MTC cases, patients with $R A S$ mutations have an intermediate risk between those with ATA-D RET mutations, which are associated with the worst prognosis, and cases with other RET mutations, that have the most indolent course.

Besides our study, only a few others that performed mutational analysis (see Table 2) have correlated genotype with patient clinical findings.

Ciampi et al. (2013) correlated the RAS mutation status in RET-negative sporadic MTC with the clinical and pathological parameters (sex, age at diagnosis, $\mathrm{T}$ categories, size of tumor, lymph node metastases, distant metastases, stage, and status of the disease) of the patients and no statistically significant differences were observed. However, a higher but not statistically significant prevalence of disease-free survival was found in the $R A S$-mutated group, suggesting that MTC harboring a $R A S$ mutation represent a subgroup of tumors with a less aggressive behavior.

In the study of Simbolo et al. (2014), clinical follow-up and serum calcitonin levels indicated that at the end of follow-up seven of 12 RET-mutated MTC patients had relapsed (six of them harbored the p.Met918Thr mutation), while the four $R A S$-mutated cases were disease free; two of the three patients with MTC WT for all 50 genes also relapsed during the follow-up period. No significant association was observed between tumor recurrence and clinicopathological/molecular features. Thus, although not fully demonstrated, it seems that $R A S$ is probably related to a less aggressive phenotype with a better outcome, and the detection of mutations by NGS may improve the diagnostic stratification of sporadic MTC.

Goutas et al. (2008) found no significant association between KRAS and BRAF mutations and clinicopathological parameters (age, gender, tumor size, stage, or nodal metastasis) in sporadic MTC. Similarly, in the study of Tamburrino et al. (2012) neither the presence nor the type of RET and RAS mutation was correlated with gender, age, histological variant (spindle cells, epithelioid), or other histological features (fibrosis, amyloid, or necrosis).

Lyra et al. (2014) attempted to correlate RAS and RET genotype results and clinicopathological data (gender, age, tumor size, nodal metastasis, invasion, or amyloid stroma) and did not disclose any associations with any clinicopathological feature for $R A S$-mutated cases; except for MTC patients displaying germline RET mutations that were younger than those with a somatic RET mutation or no RET mutation at all, no other significant association was observed between RET mutations and gender, tumor size, nodal metastasis, invasive features, or presence of amyloid stroma.

\section{RAS mutations as a therapeutic target in MTC}

Research over the last several years has enabled a good understanding of the genetic defects and altered molecular pathways that are involved in MTC development, and several promising therapeutic agents that target these specific alterations have been designed to treat advanced or metastatic MTC (Fig. 2) (Giunti et al. 2013, Haraldsdottir \& Shah 2014).

Patients with progressive MTC have been treated in the last years with small molecule tyrosine kinase inhibitors (TKI), with remarkable results (Hu et al. 2014).

Published by Bioscientifica Ltd. 
Table 5 Correlation of RET and RAS mutations with the clinical and pathological characteristics of sporadic MTC

\begin{tabular}{|c|c|c|c|c|c|}
\hline Characteristics & $\begin{array}{c}\text { Group } 1 \\
\text { p.Met918Thr and } \\
\text { p.Ala883Phe RET } \\
\text { mutation }\end{array}$ & $\begin{array}{c}\text { Group } 2 \\
\text { Other RET mutation }\end{array}$ & $\begin{array}{c}\text { Group } 3 \\
\text { No RET mutation } \\
\text { RAS mutation }\end{array}$ & $\begin{array}{c}\text { Group } 4 \\
\text { No RET mutation } \\
\text { No RAS mutation }\end{array}$ & $P$ value \\
\hline Sex & & & & & $0.756^{\mathrm{a}}$ \\
\hline Female & $50.0 \%(12 / 24)$ & $53.3 \%(8 / 15)$ & $66.7 \%(12 / 18)$ & $50.0 \%(4 / 8)$ & \\
\hline Male & $50.0 \%(12 / 24)$ & $46.7 \%(7 / 15)$ & $33.3 \%(6 / 18)$ & $50.0 \%(4 / 8)$ & \\
\hline Clinical presentation & & & & & $0.050^{\mathrm{a}}$ \\
\hline Thyroid nodule & $37.5 \%(9 / 24)$ & $100.0 \%(15 / 15)$ & $64.7 \%(11 / 17)$ & $50.0 \%(4 / 8)$ & \\
\hline Lymph node & $25.0 \%(6 / 24)$ & $0.0 \%(0 / 15)$ & $11.8 \%(2 / 17)$ & $12.5 \%(1 / 8)$ & \\
\hline Thyroid nodule and lymph node & $37.5 \%(9 / 24)$ & $0.0 \%(0 / 15)$ & $23.5 \%(4 / 17)$ & $37.5 \%(3 / 8)$ & \\
\hline $\begin{array}{l}\text { Age at surgery (years), } \\
\text { mean } \pm \text { s.E.M. }\end{array}$ & $50.88 \pm 2.82$ & $59.40 \pm 3.35$ & $60.11 \pm 3.77$ & $51.75 \pm 4.11$ & $0.1113^{b}$ \\
\hline $\begin{array}{l}\text { Tumor size }(\mathrm{cm}), \text { mean } \pm \text { S.E.M. } \\
\text { Postoperative serum calcitonin }\end{array}$ & $3.50 \pm 0.41$ & $2.81 \pm 0.44$ & $5.02 \pm 0.81$ & $3.00 \pm 0.59$ & $\begin{array}{l}0.0542^{b} \\
0.184^{a}\end{array}$ \\
\hline Undetectable & $9.1 \%(2 / 22)$ & $33.3 \%(5 / 15)$ & $25.0 \%(4 / 16)$ & $37.5 \%(3 / 8)$ & \\
\hline Detectable & $90.9 \%(20 / 22)$ & $66.7 \%(10 / 15)$ & $75.0 \%(12 / 16)$ & $62.5 \%(5 / 8)$ & \\
\hline Serum calcitonin ${ }^{c}$ at last control & & & & & $0.076^{\mathrm{a}}$ \\
\hline Undetectable & $14.3 \%(3 / 21)$ & $53.8 \%(7 / 13)$ & $37.5 \%(6 / 16)$ & $42.9 \%(3 / 7)$ & \\
\hline Detectable & $85.7 \%(18 / 21)$ & $46.2 \%(6 / 13)$ & $62.5 \%(10 / 16)$ & $57.1 \%(4 / 7)$ & \\
\hline T categories & & & & & $0.378^{\mathrm{a}}$ \\
\hline $\mathrm{T} 1$ & $12.5 \%(3 / 24)$ & $50.0 \%(7 / 14)$ & $17.6 \%(3 / 17)$ & $14.3 \%(1 / 7)$ & \\
\hline $\mathrm{T} 2$ & $37.5 \%(9 / 24)$ & $21.4 \%(3 / 14)$ & $29.4 \%(5 / 17)$ & $42.9 \%(3 / 7)$ & \\
\hline T3 & $16.7 \%(4 / 24)$ & $21.4 \%(3 / 14)$ & $17.6 \%(3 / 17)$ & $14.3 \%(1 / 7)$ & \\
\hline T4 & $33.3 \%(8 / 24)$ & $7.1 \%(1 / 14)$ & $35.3 \%(6 / 17)$ & $28.6 \%(2 / 7)$ & \\
\hline T categories grouping & & & & & $0.265^{\mathrm{a}}$ \\
\hline T1-T3 & $66.7 \%(16 / 24)$ & $92.9 \%(13 / 14)$ & $64.7 \%(11 / 17)$ & $71.4 \%(5 / 7)$ & \\
\hline T4 & $33.3 \%(8 / 24)$ & $7.1 \%(1 / 14)$ & $35.3 \%(6 / 17)$ & $28.6 \%(2 / 7)$ & \\
\hline Lymph node metastases & & & & & $0.0014^{\mathrm{d}}$ \\
\hline N1 & $87.5 \%(21 / 24)$ & $26.7 \%(4 / 15)$ & $66.7 \%(12 / 18)$ & $75.0 \%(6 / 8)$ & \\
\hline NO & $12.5 \%(3 / 24)$ & $73.3 \%(11 / 15)$ & $33.3 \%(6 / 18)$ & $25.0 \%(2 / 8)$ & \\
\hline Distant metastases & & & & & $0.027^{\mathrm{a}}$ \\
\hline M1 & $43.5 \%(10 / 23)$ & $0.0 \%(0 / 12)$ & $25.0 \%(4 / 16)$ & $14.3 \%(1 / 7)$ & \\
\hline M0 & $56.5 \%(13 / 23)$ & $100.0 \%(12 / 12)$ & $75.0 \%(12 / 16)$ & $85.7 \%(6 / 7)$ & \\
\hline Stage & & & & & $0.029^{\mathrm{a}}$ \\
\hline I & $4.2 \%(1 / 24)$ & $38.5 \%(5 / 13)$ & $11.1 \%(2 / 18)$ & $12.5 \%(1 / 8)$ & \\
\hline II & $4.2 \%(1 / 24)$ & $15.4 \%(2 / 13)$ & $22.2 \%(4 / 18)$ & $12.5 \%(1 / 8)$ & \\
\hline III & $4.2 \%(1 / 24)$ & $15.4 \%(2 / 13)$ & $5.6 \%(1 / 18)$ & $0.0 \%(0 / 8)$ & \\
\hline IV & $87.5 \%(21 / 24)$ & $30.8 \%(4 / 13)$ & $61.1 \%(11 / 18)$ & $75.0 \%(6 / 8)$ & \\
\hline Stage grouping & & & & & $0.005^{\mathrm{a}}$ \\
\hline I-III & $12.5 \%(3 / 24)$ & $69.2 \%(9 / 13)$ & $38.9 \%(7 / 18)$ & $25.0 \%(2 / 8)$ & \\
\hline IV & $87.5 \%(21 / 24)$ & $30.8 \%(4 / 13)$ & $61.1 \%(11 / 18)$ & $75.0 \%(6 / 8)$ & \\
\hline $\begin{array}{l}\text { Number of positive lymph nodes, } \\
\text { mean } \pm \text { S.E.M. }\end{array}$ & $11.29 \pm 2.01$ & $1.20 \pm 0.67$ & $6.53 \pm 1.68$ & $6.00 \pm 1.96$ & $0.0011^{\mathrm{e}}$ \\
\hline $\begin{array}{l}\text { Follow-up (months), mean } \pm \text { S.E.M. } \\
\text { Status at last control }\end{array}$ & $87.68 \pm 14.93$ & $75.93 \pm 14.81$ & $74.36 \pm 16.74$ & $61.38 \pm 25.85$ & $\begin{array}{l}0.8035^{b} \\
0.087^{\mathrm{a}}\end{array}$ \\
\hline Disease free & $14.3 \%(3 / 21)$ & $53.3 \%(8 / 15)$ & $35.3 \%(6 / 17)$ & $28.6 \%(2 / 7)$ & \\
\hline Non-disease free & $85.7 \%(18 / 21)$ & $46.7 \%(7 / 15)$ & $64.7 \%(11 / 17)$ & $71.4 \%(5 / 7)$ & \\
\hline $\begin{array}{l}\text { Presence of extraglandular } \\
\text { extension }\end{array}$ & $39.1 \%(9 / 23)$ & $7.1 \%(1 / 14)$ & $35.3 \%(6 / 17)$ & $42.9 \%(3 / 7)$ & $0.136^{\mathrm{a}}$ \\
\hline Presence of vascular invasion & $55.6 \%(10 / 18)$ & $36.4 \%(4 / 11)$ & $53.8 \%(7 / 13)$ & $71.4 \%(5 / 7)$ & $0.585^{\mathrm{a}}$ \\
\hline Presence of multifocality & $39.1 \%(9 / 23)$ & $0.0 \%(0 / 13)$ & $5.9 \%(1 / 17)$ & $28.6 \%(2 / 7)$ & $0.008^{\mathrm{a}}$ \\
\hline $\begin{array}{l}\text { Ploidy pattern } \\
\text { Diploid }\end{array}$ & & & & & $0.545^{\mathrm{a}}$ \\
\hline $\begin{array}{l}\text { Diploid } \\
\text { Aneuploid }\end{array}$ & $\begin{array}{l}87.5 \%(21 / 24) \\
12.5 \%(3 / 24)\end{array}$ & $\begin{array}{l}73.3 \%(11 / 15) \\
26.7 \%(4 / 15)\end{array}$ & $\begin{array}{l}88.9 \%(16 / 18) \\
11.1 \%(2 / 18)\end{array}$ & $\begin{array}{l}75.0 \%(6 / 8) \\
25.0 \%(2 / 8)\end{array}$ & \\
\hline S-phase fraction (\%), mean \pm S.E.M. & $7.07 \pm 0.88$ & $6.08 \pm 0.97$ & $6.57 \pm 0.89$ & $6.94 \pm 1.22$ & $0.8901^{b}$ \\
\hline
\end{tabular}

$P$ values in italics and bold are statistically significant. One $R E T$-positive sporadic MTC with a RAS mutation was excluded.

${ }^{a}$ Fisher's exact test.

bone-way ANOVA.

CCalcitonin values $<2 \mathrm{ng} / \mathrm{l}$ were regarded as undetectable.

${ }^{\mathrm{d}} \chi^{2}$ test.

${ }^{\mathrm{e}}{ }_{\text {Kruskal-Wallis test. }}$

http://erc.endocrinology-journals.org DOI: 10.1530/ERC-15-0070
(C) 2015 Society for Endocrinology Printed in Great Britain
Published by Bioscientifica Ltd. 


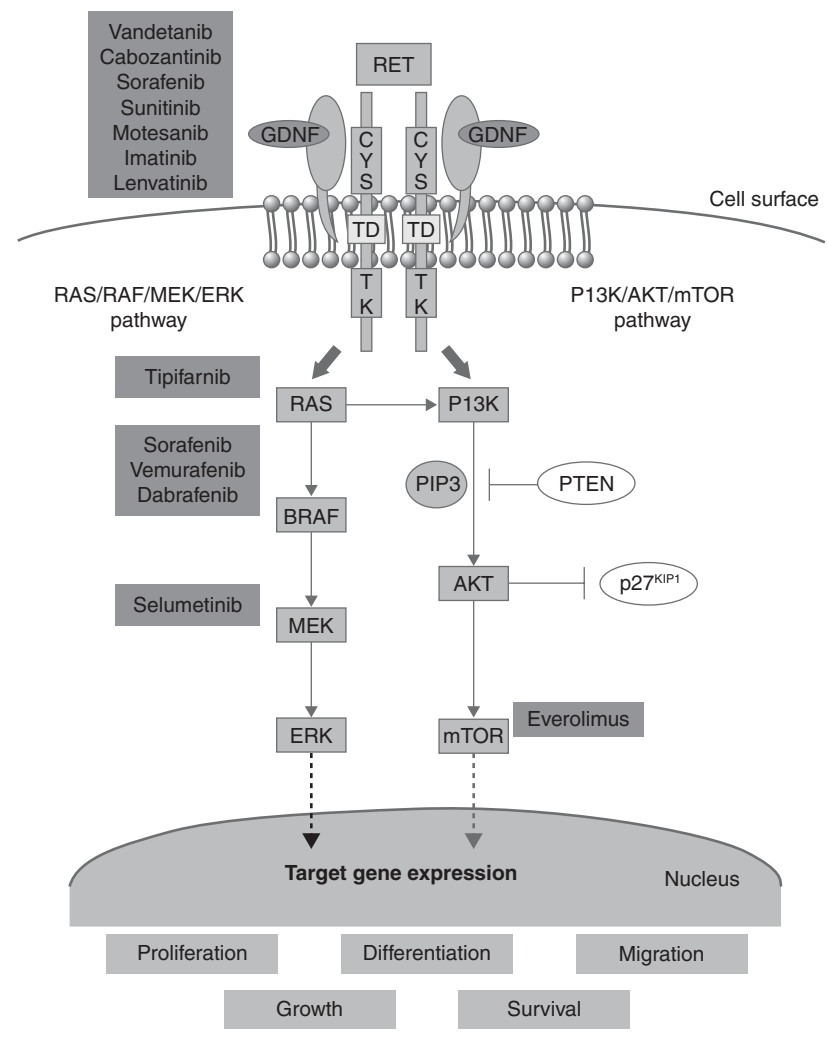

Figure 2

Signaling pathways implicated in thyroid carcinogenesis. RAS/RAF/ MEK/ERK and PI3K/AKT/mTOR pathways are involved in propagation of signals from cell membrane tyrosine kinase receptors into the nucleus and regulate multiple cellular processes, including proliferation, survival, growth, migration, and differentiation. The main therapeutic agents and their targets are shown. CYS, cysteine-rich domain; GDNF, glial cell-derived neurotrophic factor; PIP3, phosphatidylinositol $(3,4,5)$-trisphosphate; TD, transmembrane domain; TK, tyrosine kinase domain.

Some studies are targeting the RAS pathway, e.g., through the use of farnesyltransferase inhibitors (FTI), which block the main post-translational modification of the RAS protein, thus interfering with its localization to the inner surface of the plasma membrane and subsequent activation of downstream effectors (Caponigro et al. 2003). Although initially developed as an approach to target RAS in cancer, FTI have later been recognized as acting by additional and more complex mechanisms, involving RhoB, centromere-binding proteins and probably other farnesylated proteins.

Hong et al. (2008) reported on a patient with sporadic MTC with metastatic disease, who was treated with a combination of sorafenib (RET and RAF kinase and vascular endothelial growth factor receptor inhibitor) and tipifarnib (inhibitor of RAS farnesylation), which resulted in a marked clinical response. In a phase I study, it was shown that combining the multikinase inhibitor sorafenib with the FTI tipifarnib resulted in significant activity, particularly in patients with RET mutations (Hong et al. 2009). More recently, Hong et al. (2011) reported a phase I trial where 13 patients with MTC, eight of them (61.5\%) carrying germline or somatic RET mutations, were treated with sorafenib combined with tipifarnib. MTC partial response rate was 38.5\% (5/13) and stable disease of at least 6 months was 30.8\% (4/13). Unfortunately, RAS mutation status was not analyzed in these studies.

Sherman et al. $(2013 a, b)$ investigated the association of RET and RAS mutations with efficacy outcomes in the phase III study of cabozantinib in MTC (Schöffski et al. 2012). Cabozantinib is a potent inhibitor of MET, VEGFR2, and RET (Hoy 2014). Sixteen of 85 tested patients (5\% of total study patients) with WT or unknown RET status were found to harbor a RAS gene mutation and these patients presented a similar tumor response rate (31\%) and progression-free survival (47 weeks) as RET-mutated patients (32\% and 60 weeks).

Recently, it has been demonstrated that the expression of key TKI target proteins varies in MTC according to the specific RET mutation present (Rodríguez-Antona et al. 2014), a finding that could be used to improve the clinical response of MTC patients. However, the variable response to treatment with TKI remains largely unexplained and little is known about which patients would most benefit from a particular drug therapy. Mancikova et al. evaluated the influence of $R A S$ mutations on the expression levels of eight key TKI targets (EGFR, KIT, MET, PDGFRB, VEGF, VEGFR1, VEGFR2, and VEGFR3) in a series of 84 molecularly characterized primary MTC tumors (27 familial and 57 sporadic). In contrast to RET-mutated tumors, RAS-positive MTC did not express MET and PDGFRB, and stained less frequently for VEGFR3; furthermore, WT tumors expressed VEGF more often than both RAS- and RET-mutated tumors (Mancikova et al. 2014). According to these authors, the differences in drug response observed in the study of Sherman et al. $(2013 a, b)$, namely longer progression-free survival for $R E T$-mutated patients treated with cabozantinib when compared with $R A S$-mutated patients (60 weeks vs 47 weeks), could be explained, at least in part, by the differential expression of cabozantinib targets, as the RASmutated group expresses less often important targets of this drug.

These findings suggest that the assessment of RAS mutation status in sporadic RET-negative MTC can be useful to develop personalized targeted therapies.

Published by Bioscientifica Ltd 
In conclusion, analysis of RET and RAS mutations in sporadic MTC can be of value both for prognostic purposes and for therapeutic strategies.

\section{Declaration of interest}

The authors declare that there is no conflict of interest that could be perceived as prejudicing the impartiality of this review.

\section{Funding}

This review did not receive any specific grant from any funding agency in the public, commercial or not-for-profit sector.

\section{Acknowledgements}

The authors are indebted to the kind collaboration of Dr António Pinto for providing the S-phase fraction values. We thank Dr Alexandra Mayer for help with the statistical analysis. We are also grateful to Drs Ana Morgado and Ana Luísa Silva for their support in the preparation of the paper figures.

\section{References}

Abraham D, Jackson N, Gundara JS, Zhao J, Gill AJ, Delbridge L, Robinson BG \& Sidhu SB 2011 MicroRNA profiling of sporadic and hereditary medullary thyroid cancer identifies predictors of nodal metastasis, prognosis and potential therapeutic targets. Clinical Cancer Research $\mathbf{1 7}$ 4772-4781. (doi:10.1158/1078-0432.CCR-11-0242)

Agrawal N, Jiao Y, Sausen M, Leary R, Bettegowda C, Roberts NJ, Bhan S, Ho AS, Khan Z, Bishop J et al. 2013 Exomic sequencing of medullary thyroid cancer reveals dominant and mutually exclusive oncogenic mutations in RET and RAS. Journal of Clinical Endocrinology and Metabolism $\mathbf{9 8}$ E364-E369. (doi:10.1210/jc.2012-2703)

Albarel F, Conte-Devolx B \& Oliver C 2012 From nodule to differentiated thyroid carcinoma: contributions of molecular analysis in 2012. Annales d'Endocrinologie 73 155-164. (doi:10.1016/j.ando.2012.03.002)

American Thyroid Association Guidelines Task Force, Kloos RT, Eng C, Evans DB, Francis GL, Gagel RF, Gharib H, Moley JF, Pacini F, Ringel MD et al. 2009 Medullary thyroid cancer: management guidelines of the American Thyroid Association. Thyroid 19 565-612. (doi:10.1089/thy. 2008.0403)

Ameur N, Lacroix L, Motte N, Baudin E, Caillou B, Ducreux M, Elias D, Chanson P, Schlumberger M \& Bidart JM 2009 Mutational status of EGFR, BRAF, PI3KCA and JAK2 genes in endocrine tumors. International Journal of Cancer 124 751-753. (doi:10.1002/ijc.23999)

Bockhorn M, Frilling A, Kalinin V, Schröder S \& Broelsch CE 2000 Absence of $\mathrm{H}$ - and K-ras oncogene mutations in sporadic medullary thyroid carcinoma. Experimental and Clinical Endocrinology \& Diabetes 108 49-53. (doi:10.1055/s-0032-1329215)

Boguski MS \& McCormick F 1993 Proteins regulating Ras and its relatives. Nature 366 643-654. (doi:10.1038/366643a0)

Boichard A, Croux L, Al Ghuzlan A, Broutin S, Dupuy C, Leboulleux S, Schlumberger M, Bidart JM \& Lacroix L 2012 Somatic RAS mutations occur in a large proportion of sporadic RET-negative medullary thyroid carcinomas and extend to a previously unidentified exon. Journal of Clinical Endocrinology and Metabolism 97 E2031-E2035. (doi:10.1210/ jc.2012-2092)

Capon DJ, Seeburg PH, McGrath JP, Hayflick JS, Edman U, Levinson AD \& Goeddel DV 1983 Activation of Ki-ras2 gene in human colon and lung carcinomas by two different point mutations. Nature 304 507-513. (doi:10.1038/304507a0)

Caponigro F, Casale M \& Bryce J 2003 Farnesyl transferase inhibitors in clinical development. Expert Opinion on Investigational Drugs 12 943-954. (doi:10.1517/13543784.12.6.943)

Cerrato A, De Falco V \& Santoro M 2009 Molecular genetics of medullary thyroid carcinoma: the quest for novel therapeutic targets. Journal of Molecular Endocrinology 43 143-155. (doi:10.1677/JME-09-0024)

Ciampi R, Romei C, Cosci B, Vivaldi A, Bottici V, Renzini G, Ugolini C, Tacito A, Basolo F, Pinchera A et al. 2012 Chromosome 10 and RET gene copy number alterations in hereditary and sporadic medullary thyroid carcinoma. Molecular and Cellular Endocrinology 348 176-182. (doi:10.1016/j.mce.2011.08.004)

Ciampi R, Mian C, Fugazzola L, Cosci B, Romei C, Barollo S, Cirello V, Bottici V, Marconcini G, Rosa PM et al. 2013 Evidence of a low prevalence of RAS mutations in a large medullary thyroid cancer series. Thyroid 23 50-57. (doi:10.1089/thy.2012.0207)

Cote GJ \& Gagel RF 2003 Lessons learned from the management of a rare genetic cancer. New England Journal of Medicine 349 1566-1568 (doi:10.1056/NEJMe038148)

Dhar R, Ellis RW, Shih TY, Oroszlan S, Shapiro B, Maizel J, Lowy D \& Scolnick E 1982 Nucleotide sequence of the p21 transforming protein of Harvey murine sarcoma virus. Science 217 934-936. (doi:10.1126/ science.6287572)

Donis-Keller H, Dou S, Chi D, Carlson KM, Toshima K, Lairmore TC, Howe JR, Moley JF, Goodfellow P \& Wells SA Jr 1993 Mutations in the RET proto-oncogene are associated with MEN 2A and FMTC. Human Molecular Genetics 2 851-856. (doi:10.1093/hmg/2.7.851)

Dvorakova S, Vaclavikova E, Sykorova V, Vcelak J, Novak Z, Duskova J, Ryska A, Laco J, Cap J, Kodetova D et al. 2008 Somatic mutations in the RET proto-oncogene in sporadic medullary thyroid carcinomas. Molecular and Cellular Endocrinology 284 21-27. (doi:10.1016/j.mce. 2007.12.016)

Elisei R, Cosci B, Romei C, Bottici V, Renzini G, Molinaro E, Agate L, Vivaldi A, Faviana P, Basolo F et al. 2008 Prognostic significance of somatic RET oncogene mutations in sporadic medullary thyroid cancer: a 10-year follow-up study. Journal of Clinical Endocrinology and Metabolism 93 682-687. (doi:10.1210/jc.2007-1714)

Eng C 1999 RET proto-oncogene in the development of human cancer. Journal of Clinical Oncology 17 380-393.

Eng C, Smith DP, Mulligan LM, Nagai MA, Healey CS, Ponder MA, Gardner E, Scheumann GF, Jackson CE, Tunnacliffe A et al. 1994 Point mutation within the tyrosine kinase domain of the RET proto-oncogene in multiple endocrine neoplasia type $2 \mathrm{~B}$ and related sporadic tumours. Human Molecular Genetics 3 237-241. (doi:10.1093/hmg/3.2.237)

Fassan M, Realdon S, Pizzi M, Balistreri M, Battaglia G, Zaninotto G, Ancona E \& Rugge M 2012 Programmed cell death 4 nuclear loss and miR-21 or activated Akt overexpression in esophageal squamous cell carcinogenesis. Diseases of the Esophagus 25 263-268. (doi:10.1111/ j.1442-2050.2011.01236.x)

Flicker K, Ulz P, Höger H, Zeitlhofer P, Haas OA, Behmel A, Buchinger W, Scheuba C, Niederle B, Pfragner R et al. 2012 High-resolution analysis of alterations in medullary thyroid carcinoma genomes. International Journal of Cancer 131 E66-E73. (doi:10.1002/ijc.26494)

Forbes SA, Bindal N, Bamford S, Cole C, Kok CY, Beare D, Jia M, Shepherd R, Leung K, Menzies A et al. 2011 COSMIC: mining complete cancer genomes in the Catalogue of Somatic Mutations in Cancer. Nucleic Acids Research 39 D945-D950. (doi:10.1093/nar/gkq929)

Forcet C, Etienne-Manneville S, Gaude H, Fournier L, Debilly S, Salmi M, Baas A, Olschwang S, Clevers H \& Billaud M 2005 Functional analysis of Peutz-Jeghers mutations reveals that the LKB1 C-terminal region exerts a crucial role in regulating both the AMPK pathway and the cell polarity. Human Molecular Genetics 14 1283-1292. (doi:10.1093/hmg/ddi139)

Frank-Raue K, Rondot S \& Raue F 2010 Molecular genetics and phenomics of RET mutations: impact on prognosis of MTC. Molecular and Cellular Endocrinology 322 2-7. (doi:10.1016/j.mce.2010.01.012) 
Gallel P, Pallares J, Dolcet X, Llobet D, Eritja N, Santacana M, Yeramian A, Palomar-Asenjo V, Lagarda H, Mauricio D et al. 2008 Nuclear factor-кB activation is associated with somatic and germ line RET mutations in medullary thyroid carcinoma. Human Pathology 39 994-1001. (doi:10.1016/j.humpath.2007.11.015)

Garcia-Rostan G, Zhao H, Camp RL, Pollan M, Herrero A, Pardo J, Wu R, Carcangiu ML, Costa J \& Tallini G 2003 ras mutations are associated with aggressive tumor phenotypes and poor prognosis in thyroid cancer. Journal of Clinical Oncology 21 3226-3235. (doi:10.1200/JCO. 2003.10.130)

Giunti S, Antonelli A, Amorosi A \& Santarpia L 2013 Cellular signaling pathway alterations and potential targeted therapies for medullary thyroid carcinoma. International Journal of Endocrinology 2013803171. (doi:10.1155/2013/803171)

Goldfarb M, Shimizu K, Perucho M \& Wigler M 1982 Isolation and preliminary characterization of a human transforming gene from T24 bladder carcinoma cells. Nature 296 404-409. (doi:10.1038/296404a0)

Goutas N, Vlachodimitropoulos D, Bouka M, Lazaris AC, Nasioulas G \& Gazouli M 2008 BRAF and K-RAS mutation in a Greek papillary and medullary thyroid carcinoma cohort. Anticancer Research 28 305-308.

Hall A, Marshall CJ, Spurr NK \& Weiss RA 1983 Identification of transforming gene in two human sarcoma cell lines as a new member of the ras gene family located on chromosome 1. Nature 303 396-400. (doi:10.1038/303396a0)

Haraldsdottir S \& Shah MH 2014 An update on clinical trials of targeted therapies in thyroid cancer. Current Opinion in Oncology 26 36-44. (doi:10.1097/CCO.0000000000000029)

Harvey JJ 1964 An unidentified virus which causes the rapid production of tumors in mice. Nature 204 1104-1105. (doi:10.1038/2041104b0)

Hazard JB, Hawk WA \& Crile G Jr 1959 Medullary (solid) carcinoma of the thyroid; a clinicopathologic entity. Journal of Clinical Endocrinology and Metabolism 19 152-161. (doi:10.1210/jcem-19-1-152)

Herfarth KK, Wick MR, Marshall HN, Gartner E, Lum S \& Moley JF 1997 Absence of TP53 alterations in pheochromocytomas and medullary thyroid carcinomas. Genes, Chromosomes \& Cancer 20 24-29. (doi:10. 1002/(SICI)1098-2264(199709)20:1 < 24::AID-GCC4>3.0.CO;2-B)

Heshmati HM, Gharib H, van Heerden JA \& Sizemore GW 1997 Advances and controversies in the diagnosis and management of medullary thyroid carcinoma. American Journal of Medicine 103 60-69. (doi:10.1016/S0002-9343(97)00024-7)

Hong D, Ye L, Gagel R, Chintala L, El Naggar AK, Wright J \& Kurzrock R 2008 Medullary thyroid cancer: targeting the RET kinase pathway with sorafenib/tipifarnib. Molecular Cancer Therapeutics 7 1001-1006. (doi:10.1158/1535-7163.MCT-07-2422)

Hong DS, Sebti SM, Newman RA, Blaskovich MA, Ye L, Gagel RF, Moulder S, Wheler JJ, Naing A, Tannir NM et al. 2009 Phase I trial of a combination of the multikinase inhibitor sorafenib and the farnesyltransferase inhibitor tipifarnib in advanced malignancies. Clinical Cancer Research 15 7061-7068. (doi:10.1158/1078-0432.CCR-09-1241)

Hong DS, Cabanillas ME, Wheler J, Naing A, Tsimberidou AM, Ye L, Busaidy NL, Waguespack SG, Hernandez M, El Naggar AK et al. 2011 Inhibition of the Ras/Raf/MEK/ERK and RET kinase pathways with the combination of the multikinase inhibitor sorafenib and the farnesyltransferase inhibitor tipifarnib in medullary and differentiated thyroid malignancies. Journal of Clinical Endocrinology and Metabolism 96 997-1005. (doi:10.1210/jc.2010-1899)

Horie H, Yokogoshi Y, Tsuyuguchi M \& Saito S 1995 Point mutations of ras and Gs $\alpha$ subunit genes in thyroid tumors. Japanese Journal of Cancer Research 86 737-742. (doi:10.1111/j.1349-7006.1995.tb02462.x)

Hoy SM 2014 Cabozantinib: a review of its use in patients with medullary thyroid cancer. Drugs 74 1435-1444. (doi:10.1007/s40265-014-0265-x)

Hu MI, Ying AK \& Jimenez C 2014 Update on medullary thyroid cancer. Endocrinology and Metabolism Clinics of North America 43 423-442. (doi:10.1016/j.ecl.2014.02.004)

Hundahl SA, Fleming ID, Fremgen AM \& Menck HR 1998 A National Cancer Data Base report on 53,856 cases of thyroid carcinoma treated in the U.S., 1985-1995. Cancer 83 2638-2648. (doi:10.1002/(SICI)10970142(19981215)83:12<2638::AID-CNCR31>3.0.CO;2-1)

Janakiraman M, Vakiani E, Zeng Z, Pratilas CA, Taylor BS, Chitale D, Halilovic E, Wilson M, Huberman K, Ricarte Filho JC et al. 2010 Genomic and biological characterization of exon 4 KRAS mutations in human cancer. Cancer Research 70 5901-5911. (doi:10.1158/00085472.CAN-10-0192)

Jaquet AJ 1906 Ein Fall von metastasierenden Amyloidtumoren (Lymphosarkom). Virchows Archiv 185 251-267. (doi:10.1007/BF01948712)

Johnston D, Hatzis D \& Sunday ME 1998 Expression of v-Ha-ras driven by the calcitonin/calcitonin gene-related peptide promoter: a novel transgenic murine model for medullary thyroid carcinoma. Oncogene 16 167-177. (doi:10.1038/sj.onc.1201478)

Killela PJ, Reitman ZJ, Jiao Y, Bettegowda C, Agrawal N, Diaz LA Jr, Friedman AH, Friedman H, Gallia GL, Giovanella BC et al. 2013 TERT promoter mutations occur frequently in gliomas and a subset of tumors derived from cells with low rates of self-renewal. PNAS 110 6021-6026. (doi:10.1073/pnas.1303607110)

Kirsten WH \& Mayer LA 1967 Morphologic responses to a murine erythroblastosis virus. Journal of the National Cancer Institute 39 311-335.

Koch CA, Brouwers FM, Vortmeyer AO, Tannapfel A, Libutti SK, Zhuang Z, Pacak K, Neumann HP \& Paschke R 2006 Somatic VHL gene alterations in MEN2-associated medullary thyroid carcinoma. BMC Cancer 6131. (doi:10.1186/1471-2407-6-131)

Koperek O, Bergner O, Pichlhöfer B, Oberndorfer F, Hainfellner JA, Kaserer K, Horvat R, Harris AL, Niederle B \& Birner P 2011 Expression of hypoxiaassociated proteins in sporadic medullary thyroid cancer is associated with desmoplastic stroma reaction and lymph node metastasis and may indicate somatic mutations in the VHL gene. Journal of Pathology 225 63-72. (doi:10.1002/path.2926)

Kouvaraki MA, Shapiro SE, Perrier ND, Cote GJ, Gagel RF, Hoff AO, Sherman SI, Lee JE \& Evans DB 2005 RET proto-oncogene: a review and update of genotype-phenotype correlations in hereditary medullary thyroid cancer and associated endocrine tumors. Thyroid 15 531-544. (doi:10.1089/thy.2005.15.531)

Lemoine NR, Mayall ES, Wyllie FS, Farr CJ, Hughes D, Padua RA, Thurston V, Williams ED \& Wynford-Thomas D 1988 Activated ras oncogenes in human thyroid cancers. Cancer Research 48 4459-4463.

Lyra J, Vinagre J, Batista R, Pinto V, Prazeres H, Rodrigues F, Eloy C, Sobrinho-Simões M \& Soares P 2014 mTOR activation in medullary thyroid carcinoma with RAS mutation. European Journal of Endocrinology 171 633-640. (doi:10.1530/EJE-14-0389)

Maliszewska A, Leandro-Garcia LJ, Castelblanco E, Macià A, de Cubas A, Goméz-López G, Inglada-Pérez L, Álvarez-Escolá C, De la Vega L, Letón R et al. 2013 Differential gene expression of medullary thyroid carcinoma reveals specific markers associated with genetic conditions. American Journal of Pathology 182 350-362. (doi:10.1016/j.ajpath.2012.10.025)

Mancikova V, Inglada-Pérez L, Curras-Freixes M, de Cubas AA, Gómez Á, Letón R, Kersten I, Leandro-García LJ, Comino-Méndez I, ApellanizRuiz M et al. 2014 VEGF, VEGFR3, and PDGFRB protein expression is influenced by RAS mutations in medullary thyroid carcinoma. Thyroid 24 1251-1255. (doi:10.1089/thy.2013.0579)

Martins RG, Rajendran JG, Capell P, Byrd DR \& Mankoff DA 2006 Medullary thyroid cancer: options for systemic therapy of metastatic disease? Journal of Clinical Oncology 24 1653-1655. (doi:10.1200/JCO. 2005.05.4106)

Mian C, Pennelli G, Barollo S, Cavedon E, Nacamulli D, Vianello F, Negro I, Pozza G, Boschin IM, Pelizzo MR et al. 2011 Combined RET and Ki-67 assessment in sporadic medullary thyroid carcinoma: a useful tool for patient risk stratification. European Journal of Endocrinology 164 971-976. (doi:10.1530/EJE-11-0079)

Mian C, Pennelli G, Fassan M, Balistreri M, Barollo S, Cavedon E, Galuppini F, Pizzi M, Vianello F, Pelizzo MR et al. 2012 MicroRNA profiles in familial and sporadic medullary thyroid carcinoma: preliminary 
relationships with RET status and outcome. Thyroid 22 890-896. (doi:10.1089/thy.2012.0045)

Moura MM, Cavaco BM, Pinto AE, Domingues R, Santos JR, Cid MO, Bugalho MJ \& Leite V 2009 Correlation of RET somatic mutations with clinicopathological features in sporadic medullary thyroid carcinomas. British Journal of Cancer 100 1777-1783. (doi:10.1038/sj.bjc.6605056)

Moura MM, Cavaco BM, Pinto AE \& Leite V 2011 High prevalence of RAS mutations in RET-negative sporadic medullary thyroid carcinomas. Journal of Clinical Endocrinology and Metabolism 96 E863-E868. (doi:10.1210/jc.2010-1921)

Naguib A, Wilson CH, Adams DJ \& Arends MJ 2011 Activation of K-RAS by co-mutation of codons 19 and 20 is transforming. Journal of Molecular Signaling 6 2. (doi:10.1186/1750-2187-6-2)

Nakagawa T, Mabry M, de Bustros A, Ihle JN, Nelkin BD \& Baylin SB 1987 Introduction of $\mathrm{v}$-Ha-ras oncogene induces differentiation of cultured human medullary thyroid carcinoma cells. PNAS 84 5923-5927. (doi:10.1073/pnas.84.16.5923)

Namba H, Rubin SA \& Fagin JA 1990 Point mutations of ras oncogenes are an early event in thyroid tumorigenesis. Molecular Endocrinology 4 1474-1479. (doi:10.1210/mend-4-10-1474)

Nikiforova MN, Kimura ET, Gandhi M, Biddinger PW, Knauf JA, Basolo F, Zhu Z, Giannini R, Salvatore G, Fusco A et al. 2003 BRAF mutations in thyroid tumors are restricted to papillary carcinomas and anaplastic or poorly differentiated carcinomas arising from papillary carcinomas. Journal of Clinical Endocrinology and Metabolism 88 5399-5404. (doi:10.1210/jc.2003-030838)

Nikiforova MN, Tseng GC, Steward D, Diorio D \& Nikiforov YE 2008 MicroRNA expression profiling of thyroid tumors: biological significance and diagnostic utility. Journal of Clinical Endocrinology and Metabolism 93 1600-1608. (doi:10.1210/jc.2007-2696)

Nikiforova MN, Wald AI, Roy S, Durso MB \& Nikiforov YE 2013 Targeted next-generation sequencing panel (ThyroSeq) for detection of mutations in thyroid cancer. Journal of Clinical Endocrinology and Metabolism 98 E1852-E1860. (doi:10.1210/jc.2013-2292)

Okazaki M, Miya A, Tanaka N, Miki T, Yamamoto M, Motomura K, Miyauchi A, Mori T \& Takai S 1989 Allele loss on chromosome 10 and point mutation of ras oncogenes are infrequent in tumors of MEN 2A. Henry Ford Hospital Medical Journal 37 112-115.

Pacini F, Castagna MG, Brilli L, Pentheroudakis G \& ESMO Guidelines Working Group 2010 Thyroid cancer: ESMO Clinical Practice Guidelines for diagnosis, treatment and follow-up. Annals of Oncology 21 (Suppl 5) v214-v219. (doi:10.1093/annonc/mdq190)

Palamarchuk A, Efanov A, Maximov V, Aqeilan RI, Croce CM \& Pekarsky Y 2005 Akt phosphorylates and regulates Pdcd 4 tumor suppressor protein. Cancer Research 65 11282-11286. (doi:10.1158/0008-5472.CAN05-3469)

Peixoto Callejo I, Américo Brito J, Zagalo CM \& Rosa Santos J 2006 Medullary thyroid carcinoma: multivariate analysis of prognostic factors influencing survival. Clinical \& Translational Oncology 8 435-443. (doi:10.1007/s12094-006-0198-2)

Pennelli G, Galuppini F, Barollo S, Cavedon E, Bertazza L, Fassan M, Guzzardo V, Pelizzo MR, Rugge M \& Mian C 2015 The PDCD4/miR-21 pathway in medullary thyroid carcinoma. Human Pathology 46 50-57. (doi:10.1016/j.humpath.2014.09.006)

Perren A, Schmid S, Locher T, Saremaslani P, Bonvin C, Heitz PU \& Komminoth P 2004 BRAF and endocrine tumors: mutations are frequent in papillary thyroid carcinomas, rare in endocrine tumors of the gastrointestinal tract and not detected in other endocrine tumors. Endocrine-Related Cancer 11 855-860. (doi:10.1677/erc.1.00841)

Peters RL, Rabstein LS, VanVleck R, Kelloff GJ \& Huebner RJ 1974 Naturally occurring sarcoma virus of the BALB/cCr mouse. Journal of the National Cancer Institute 53 1725-1729.

Pinkel D \& Albertson DG 2005 Array comparative genomic hybridization and its applications in cancer. Nature Genetics 37 (Suppl) S11-S17. (doi:10.1038/ng1569)
Pita JM, Figueiredo IF, Moura MM, Leite V \& Cavaco BM 2014 Cell cycle deregulation and TP53 and RAS mutations are major events in poorly differentiated and undifferentiated thyroid carcinomas. Journal of Clinical Endocrinology and Metabolism 99 E497-E507. (doi:10.1210/jc. 2013-1512)

Ponder BA, Ponder MA, Coffey R, Pembrey ME, Gagel RF, Telenius-Berg M, Semple P \& Easton DF 1988 Risk estimation and screening in families of patients with medullary thyroid carcinoma. Lancet $1397-401$. (doi:10.1016/S0140-6736(88)91191-9)

Prior IA, Lewis PD \& Mattos C 2012 A comprehensive survey of Ras mutations in cancer. Cancer Research 72 2457-2467. (doi:10.1158/00085472.CAN-11-2612)

Pulciani S, Santos E, Lauver AV, Long LK, Robbins KC \& Barbacid M 1982 Oncogenes in human tumor cell lines: molecular cloning of a transforming gene from human bladder carcinoma cells. PNAS 79 2845-2849. (doi:10.1073/pnas.79.9.2845)

Pulciani S, Santos E, Long LK, Sorrentino V \& Barbacid M 1985 ras gene Amplification and malignant transformation. Molecular and Cellular Biology 5 2836-2841. (doi:10.1128/MCB.5.10.2836)

Puppin C, Durante C, Sponziello M, Verrienti A, Pecce V, Lavarone E, Baldan F, Campese AF, Boichard A, Lacroix L et al. 2014 Overexpression of genes involved in miRNA biogenesis in medullary thyroid carcinomas with RET mutation. Endocrine 47 528-536. (doi:10.1007/ s12020-014-0204-3)

Pylayeva-Gupta Y, Grabocka E \& Bar-Sagi D 2011 RAS oncogenes: weaving a tumorigenic web. Nature Reviews. Cancer 11 761-774. (doi:10.1038/ nrc3106)

Rapa I, Saggiorato E, Giachino D, Palestini N, Orlandi F, Papotti M \& Volante M 2011 Mammalian target of rapamycin pathway activation is associated to RET mutation status in medullary thyroid carcinoma. Journal of Clinical Endocrinology and Metabolism 96 2146-2153. (doi:10.1210/jc.2010-2655)

Rasheed S, Gardner MB \& Huebner RJ 1978 In vitro isolation of stable rat sarcoma viruses. PNAS 75 2972-2976. (doi:10.1073/pnas.75.6.2972)

Reddy EP, Reynolds RK, Santos E \& Barbacid M 1982 A point mutation is responsible for the acquisition of transforming properties by the T24 human bladder carcinoma oncogene. Nature 300 149-152. (doi:10.1038/300149a0)

Rodríguez-Antona C, Muñoz-Repeto I, Inglada-Pérez L, de Cubas AA Mancikova V, Cañamero M, Maliszewska A, Gómez A, Letón R, Leandro-García LJ et al. 2013 Influence of RET mutations on the expression of tyrosine kinases in medullary thyroid carcinoma. Endocrine-Related Cancer 20 611-619. (doi:10.1530/ERC-12-0316)

Roman S, Lin R \& Sosa JA 2006 Prognosis of medullary thyroid carcinoma: demographic, clinical and pathologic predictors of survival in 1252 cases. Cancer 107 2134-2142. (doi:10.1002/cncr.22244)

Romei C, Cosci B, Renzini G, Bottici V, Molinaro E, Agate L, Passannanti P, Viola D, Biagini A, Basolo F et al. 2011 RET genetic screening of sporadic medullary thyroid cancer (MTC) allows the preclinical diagnosis of unsuspected gene carriers and the identification of a relevant percentage of hidden familial MTC (FMTC). Clinical Endocrinology 74 241-247. (doi:10.1111/j.1365-2265.2010.03900.x)

Schlumberger MJ, Elisei R, Bastholt L, Wirth LJ, Martins RG, Locati LD, Jarzab B, Pacini F, Daumerie C, Droz JP et al. 2009 Phase II study of safety and efficacy of motesanib in patients with progressive or symptomatic, advanced or metastatic medullary thyroid cancer. Journal of Clinical Oncology 27 3794-3801. (doi:10.1200/JCO.2008.18.7815)

Schöffski P, Elisei R, Müller S, Brose MS, Shah MH, Licitra LF, Jarzab B, Medvedev V, Kreissl M, Niederle B et al. 2012 An international, doubleblind, randomized, placebo-controlled phase III trial (EXAM) of cabozantinib (XL184) in medullary thyroid carcinoma (MTC) patients (pts) with documented RECIST progression at baseline. Journal of Clinical Oncology 30 (Suppl) Abstr 5508.

Schulten HJ, Al-Maghrabi J, Al-Ghamdi K, Salama S, Al-Muhayawi S, Chaudhary A, Hamour O, Abuzenadah A, Gari M \& Al-Qahtani M 2011 Mutational screening of RET, HRAS, KRAS, NRAS, BRAF, AKT1 and 
CTNNB1 in medullary thyroid carcinoma. Anticancer Research $\mathbf{3 1}$ 4179-4183.

Sherman SI, Cohen EEW, Schöffski P, Elisei R, Schlumberger M, Wirth LJ, Mangeshkar M, Aftab DT, Clary DO \& Brose MS 2013a Efficacy of cabozantinib (Cabo) in medullary thyroid cancer (MTC) patients with RAS or RET mutations: results from a phase III study. Journal of Clinical Oncology 31 (Suppl) Abstr 6000.

Sherman SI, Cohen EEW, Schöffski P, Elisei R, Schlumberger M, Wirth L, Mangeshkar M, Aftab DT, Clary DO \& Brose M 2013 $b$ Efficacy of cabozantinib in a phase 3 study of medullary thyroid cancer (MTC) patients with RET or RAS mutations. European Thyroid Journal 2 (Suppl) Abstr OP01.

Shih C \& Weinberg RA 1982 Isolation of a transforming sequence from a human bladder carcinoma cell line. Cell 29 161-169. (doi:10.1016/ 0092-8674(82)90100-3)

Shimizu K, Goldfarb M, Perucho M \& Wigler M 1983 Isolation and preliminary characterization of the transforming gene of a human neuroblastoma cell line. PNAS 80383-387. (doi:10.1073/pnas.80.2.383)

Simbolo M, Mian C, Barollo S, Fassan M, Mafficini A, Neves D, Scardoni M, Pennelli G, Rugge M, Pelizzo MR et al. 2014 High-throughput mutation profiling improves diagnostic stratification of sporadic medullary thyroid carcinomas. Virchows Archiv 465 73-78. (doi:10.1007/s00428-014-1589-3)

Sponziello M, Durante C, Boichard A, Dima M, Puppin C, Verrienti A, Tamburrano G, Di Rocco G, Redler A, Lacroix L et al. 2014 Epigeneticrelated gene expression profile in medullary thyroid cancer revealed the overexpression of the histone methyltransferases EZH2 and SMYD3 in aggressive tumours. Molecular and Cellular Endocrinology 392 8-13. (doi:10.1016/j.mce.2014.04.016)

Stamatakos M, Paraskeva P, Stefanaki C, Katsaronis P, Lazaris A, Safioleas K \& Kontzoglou K 2011 Medullary thyroid carcinoma: the third most common thyroid cancer reviewed. Oncology Letters 2 49-53. (doi:10.3892/ol.2010.223)

Suárez HG, Du Villard JA, Caillou B, Schlumberger M, Tubiana M, Parmentier C \& Monier R 1988 Detection of activated ras oncogenes in human thyroid carcinomas. Oncogene 2 403-406.

Tabin CJ, Bradley SM, Bargmann CI, Weinberg RA, Papageorge AG, Scolnick EM, Dhar R, Lowy DR \& Chang EH 1982 Mechanism of activation of a human oncogene. Nature 300 143-149. (doi:10.1038/ 300143a0)

Takahashi M, Ritz J \& Cooper GM 1985 Activation of a novel human transforming gene, ret, by DNA rearrangement. Cell 42 581-588. (doi:10.1016/0092-8674(85)90115-1)

Tamburrino A, Molinolo AA, Salerno P, Chernock RD, Raffeld M, Xi L, Gutkind JS, Moley JF, Wells SA Jr \& Santoro M 2012 Activation of the mTOR pathway in primary medullary thyroid carcinoma and lymph node metastases. Clinical Cancer Research 18 3532-3540. (doi:10.1158/ 1078-0432.CCR-11-2700)

Taparowsky E, Suard Y, Fasano O, Shimizu K, Goldfarb M \& Wigler M 1982 Activation of the T24 bladder carcinoma transforming gene is linked to a single amino acid change. Nature 300 762-765. (doi:10.1038/ 300762a0)

Tidyman WE \& Rauen KA 2009 The RASopathies: developmental syndromes of Ras/MAPK pathway dysregulation. Current Opinion in Genetics \& Development 19 230-236. (doi:10.1016/j.gde.2009.04.001)

Tsuchida N, Ryder T \& Ohtsubo E 1982 Nucleotide sequence of the oncogene encoding the p21 transforming protein of Kirsten murine sarcoma virus. Science 217 937-939. (doi:10.1126/science.6287573)
Vasko V, Ferrand M, Di Cristofaro J, Carayon P, Henry JF \& de Micco C 2003 Specific pattern of RAS oncogene mutations in follicular thyroid tumors. Journal of Clinical Endocrinology and Metabolism 88 2745-2752. (doi:10.1210/jc.2002-021186)

van Veelen W, Klompmaker R, Gloerich M, van Gasteren CJ, Kalkhoven E, Berger R, Lips CJ, Medema RH, Höppener JW \& Acton DS 2009 P18 is a tumor suppressor gene involved in human medullary thyroid carcinoma and pheochromocytoma development. International Journal of Cancer 124 339-345. (doi:10.1002/ijc.23977)

Vinagre J, Almeida A, Pópulo H, Batista R, Lyra J, Pinto V, Coelho R, Celestino R, Prazeres H, Lima L et al. 2013 Frequency of TERT promoter mutations in human cancers. Nature Communications 4 2185. (doi:10. 1038/ncomms3185)

Wells SA Jr, Robinson BG, Gagel RF, Dralle H, Fagin JA, Santoro M, Baudin E, Elisei R, Jarzab B, Vasselli JR et al. 2012 Vandetanib in patients with locally advanced or metastatic medullary thyroid cancer: a randomized, double-blind phase III trial. Journal of Clinical Oncology 30 134-141. (doi:10.1200/JCO.2011.35.5040)

Williams ED 1966 Histogenesis of medullary carcinoma of the thyroid. Journal of Clinical Pathology 19 114-118. (doi:10.1136/jcp.19.2.114)

Wolfe HJ, Melvin KE, Cervi-Skinner SJ, Saadi AA, Juliar JF, Jackson CE \& Tashjian AH Jr 1973 C-cell hyperplasia preceding medullary thyroid carcinoma. New England Journal of Medicine 289 437-441. (doi:10.1056/ NEJM197308302890901)

Wright PA, Lemoine NR, Mayall ES, Wyllie FS, Hughes D, Williams ED \& Wynford-Thomas D 1989 Papillary and follicular thyroid carcinomas show a different pattern of ras oncogene mutation. British Journal of Cancer 60 576-577. (doi:10.1038/bjc.1989.316)

Wu G, Mambo E, Guo Z, Hu S, Huang X, Gollin SM, Trink B, Ladenson PW, Sidransky D \& Xing M 2005 Uncommon mutation, but common amplifications, of the PIK3CA gene in thyroid tumors. Journal of Clinical Endocrinology and Metabolism 90 4688-4693. (doi:10.1210/ jc.2004-2281)

Xing M 2005 BRAF mutation in thyroid cancer. Endocrine-Related Cancer 12 245-262. (doi:10.1677/erc.1.0978)

Xing M, Vasko V, Tallini G, Larin A, Wu G, Udelsman R, Ringel MD, Ladenson PW \& Sidransky D 2004 BRAF T1796A transversion mutation in various thyroid neoplasms. Journal of Clinical Endocrinology and Metabolism 89 1365-1368. (doi:10.1210/jc.2003-031488)

Yana I, Nakamura T, Shin E, Karakawa K, Kurahashi H, Kurita Y, Kobayashi T, Mori T, Nishisho I \& Takai S 1992 Inactivation of the p53 gene is not required for tumorigenesis of medullary thyroid carcinoma or pheochromocytoma. Japanese Journal of Cancer Research 83 1113-1116. (doi:10.1111/j.1349-7006.1992.tb02730.x)

Yang KP, Castillo SG, Nguyen CV, Hickey RC \& Samaan NA 1990 C-myc, $\mathrm{N}$-myc, N-ras and c-erb-B: lack of amplification or rearrangement in human medullary thyroid carcinoma and a derivative cell line. Anticancer Research 10 189-192.

Yoshimoto K, Iwahana H, Fukuda A, Sano T, Saito S \& Itakura M 1992 Role of p53 mutations in endocrine tumorigenesis: mutation detection by polymerase chain reaction-single strand conformation polymorphism. Cancer Research 52 5061-5064.

Zhu Z, Gandhi M, Nikiforova MN, Fischer AH \& Nikiforov YE 2003 Molecular profile and clinical-pathologic features of the follicular variant of papillary thyroid carcinoma. An unusually high prevalence of ras mutations. American Journal of Clinical Pathology 120 71-77. (doi:10.1309/ND8D9LAJTRCTG6QD)

Received in final form 19 June 2015

Accepted 8 July 2015 http://erc.endocrinology-journals.org

DOI: 10.1530/ERC-15-0070
(C) 2015 Society for Endocrinology Printed in Great Britain
Published by Bioscientifica Ltd. 